\title{
Tick- and flea-borne rickettsial emerging zoonoses
}

\author{
Philippe PAROLA ${ }^{\mathrm{a}}$, Bernard DAvOUST ${ }^{\mathrm{b}}$, Didier RAOUlT $^{\mathrm{a} *}$ \\ ${ }^{\text {a }}$ Unité des Rickettsies, CNRS UMR 6020, IFR 48, Faculté de Médecine, Université de la Méditerranée, \\ 13385 Marseille Cedex 5, France \\ b Direction Régionale du Service de Santé des Armées, BP 16, 69998 Lyon Armées, France
}

(Received 30 March 2004; accepted 5 August 2004)

\begin{abstract}
Between 1984 and 2004, nine more species or subspecies of spotted fever rickettsiae were identified as emerging agents of tick-borne rickettsioses throughout the world. Six of these species had first been isolated from ticks and later found to be pathogenic to humans. The most recent example is Rickettsia parkeri, recognized as a human pathogen more than 60 years after its initial isolation from ticks. A new spotted fever rickettsia, $R$. felis was also found to be associated with fleas and to be a human pathogen. Similarly, bacteria within the family Anaplasmataceae have been considered to be of veterinary importance only, yet three species have been implicated in human diseases in recent years, including Ehrlichia chaffeensis, the agent of human monocytic ehrlichiosis, Anaplasma phagocytophilum, the agent of human anaplasmosis (formerly known as "human granulocytic ehrlichiosis agent", E. equi and E. phagocytophila), and finally Ehrlichia ewingii, which causes granulocytic ehrlichiosis in humans. We present here an overview of the various tick- and flea-borne rickettsial zoonoses described in the last 20 years, focusing on the ecological, epidemiological and clinical aspects.
\end{abstract}

ticks / fleas / Rickettsia / Anaplasma / zoonoses

\section{Table of contents}

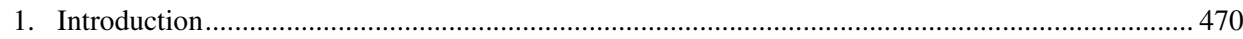

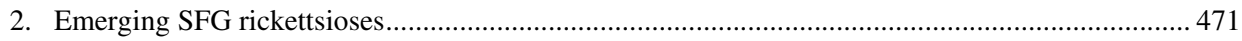

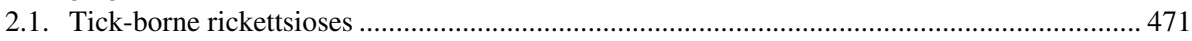

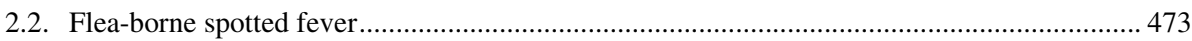

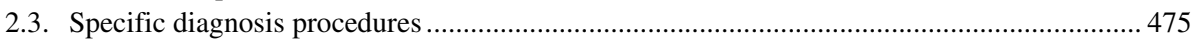

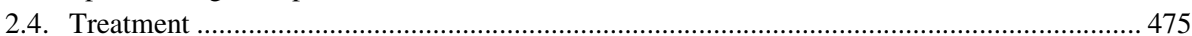

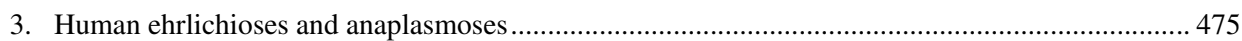

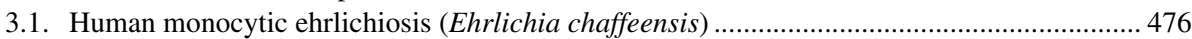

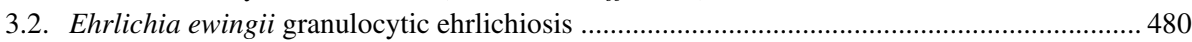

3.3. Human granulocytic anaplasmosis (formerly human granulocytic ehrlichiosis)................... 481

3.3.1. Natural history of Anaplasma phagocytophilum ................................................ 481

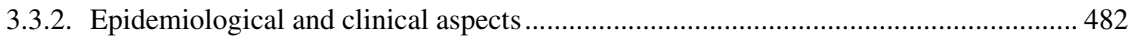

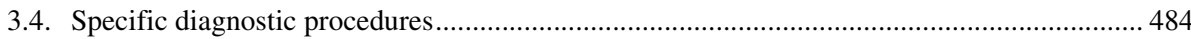

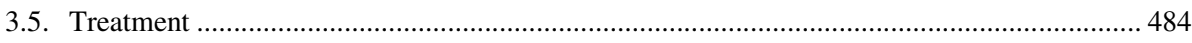

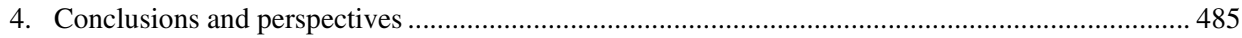

\footnotetext{
*Corresponding author: Didier.raoult@medecine.univ-mrs.fr
} 


\section{INTRODUCTION}

Rickettsial diseases are zoonoses caused by obligate intracellular bacteria grouped in the order Rickettsiales. Although the bacteria of this order were first described as short, Gram-negative rods that retained basic fuchsin when stained by the method of Gimenez, the taxonomy of rickettsias has undergone significant reorganization in the last decade. For example, Coxiella burnetii, the agent of $\mathrm{Q}$ fever has recently been removed from Rickettsiales [117]. To date, three groups of diseases are still commonly classified as rickettsial diseases. These include (i) rickettsioses due to bacteria of the genus Rickettsia, including the spotted fever group and the typhus group rickettsiae, (ii) ehrlichioses and anaplasmoses due to bacteria within the family Anaplasmataceae which has been reorganized, and (iii) scrub typhus due to Orientia tsutsugamushi [37, 58, 117, 151]. Since scrub typhus is transmitted by trombiculid mites in the Asian-Pacific region, it will not been reviewed here [151].

The classification within Rickettsiales is continually modified as new data become available, particularly those based on molecular phylogenetic studies. However, experts in the field of rickettsiology frequently disagree over species definitions. In this review we use currently accepted taxa, as well as names of species or subspecies proposed recently that are based on polyphasic taxonomic studies which integrate phenotypic and phylogenetic data [49].

Since the beginning of the 20th century, ticks and fleas have been implicated as vectors, reservoirs, and/or amplifiers of some rickettsial bacteria recognized as agents of human zoonoses [117]. The rat flea, Xenopsylla cheopis, is the main vector of murine typhus due to Rickettsia typhi, a typhus group rickettsia whereas rodents, mainly Rattus norvegicus and $R$. rattus, act as reservoirs [117]. Ixodids (hard ticks) were first implicated as vectors of spotted fever group rickettsioses in 1906, when the Rocky Mountain wood tick was shown to transmit
Rickettsia rickettsii, the agent of Rocky Mountain spotted fever in the USA [126, 154]. Interestingly, $R$. rickettsii was considered as the only agent of tick-borne rickettsioses in America throughout the 20th century. Although other spotted fever group (SFG) rickettsiae were detected from ticks there, these were considered as "non-pathogenic" rickettsiae [116, 117]. At the same time, other continents were considered to have their specific tick-borne pathogenic rickettsia such as $R$. conorii (in Europe and Africa), R. sibirica (in the former USSR and China), and $R$. australis (in Australia) [117]. However, between 1984 and 2004, nine more species or subspecies of tickborne spotted fever rickettsiae were identified as emerging pathogens throughout the world [116, 117]. A new spotted fever group rickettsia, $R$. felis was also found to be associated with fleas and to be pathogenic to humans [59].

Similarly, bacteria within the family Anaplasmataceae have long been considered to be only of veterinary importance, yet three species have been implicated in human diseases in recent years. The first human case of monocytic ehrlichiosis (HME) was described in 1987 in the USA and first assumed to be due to Ehrlichia canis, the agent of canine monocytic ehrlichiosis [81]. The causative agent of HME, Ehrlichia chaffeensis, was later isolated in 1991 in the USA [34]. In 1994, human granulocytic ehrlichiosis was first described in the USA [30] and has subsequently been shown to occur in Europe [110]. The causative organism, first known as the "HGE agent" had been found to be closely related to E. equi and E. phagocytophila (pathogens of horses and ruminants, respectively). However, phylogenic studies showed that insufficient differences exist among these three to support separate species designations. Therefore these agents are grouped with Anaplasma spp. [37]. Currently, all three are considered as a single species, Anaplasma phagocytophilum and the disease has now been renamed as human granulocytic anaplasmosis. Finally, Ehrlichia 
ewingii, the agent of canine granulocytic ehrlichiosis, was found in 1999 to cause disease in humans [24].

Here we present an overview of the various tick- and flea borne rickettsial zoonoses described in the last 20 years, focusing on the ecological, epidemiological and clinical aspects.

\section{EMERGING SFG RICKETTSIOSES}

\subsection{Tick-borne rickettsioses}

Between 1984 and 2004, nine more species or subspecies of tick-borne spotted fever rickettsiae were identified as emerging pathogens throughout the world, including, $R$. japonica in Japan $[6,46,65,71,72,82-$ 84, 146]; " $R$. conorii caspia" in Astrakhan [35, 38, 39, 143], Africa [47] and Kosovo [48]; R. africae in sub-Saharan Africa and the West Indies [62, 63]; R. honei in the Flinders Island, offshore of Australia [9, 57, 140, 141], the Island of Tasmania, Australia [153], Thailand [73], and possibly in the USA [13]; $R$. slovaca in Europe [29, 74, $101,122]$; " $R$. sibirica mongolotimonae" in China [157], Europe [44, 118] and Africa $[106,113] ; R$. heilongjiangensis in China $[42,49]$; $R$. aeschlimannii in Africa [11, 112, 121] and Europe [43]; and finally $R$. parkeri in the USA [104]. $R$. helvetica is also suspected to be a human pathogen in Europe [45] and Asia [46, 61, 107], but this needs confirmation. Interestingly, out of the nine tick-borne SFG rickettsiae recently found to be pathogens for people after 1984, six were first isolated from ticks and later found to be pathogenic to humans. The delay between their isolation from ticks and their implication in human diseases ranged up to 65 years, in the case of $R$. parkeri which was considered a "non pathogenic rickettsia" until 2004 in the USA [104].

Ixodids (hard ticks) may act as vectors, reservoirs, and/or amplifiers of spotted fever group rickettsiae. Humans are inci- dental hosts when they are bitten by ticks. When transmitted to people, the pathogenic rickettsiae multiply in endothelial cells causing a vasculitis which is responsible for the clinical and laboratory abnormalities of rickettsioses $[117,150]$. Ecological characteristics of the tick vectors are keys for the epidemiology of tick-borne diseases [105]. For example, Dermacentor ticks are well known to bite people on the scalp in Europe. As a consequence, the inoculation eschar in $R$. slovaca infection, which is transmitted by Dermacentor spp. in Europe, is located on the scalp [122]. On the contrary, Amblyomma hebraeum which are known as vectors of $R$. africae in southern Africa, emerge from their habitats and actively attack animals including people if they enter their biotopes such as the bush during safaris. Numerous ticks can attack a host at the same time and Amblyomma spp. are highly infected by rickettsiae [62, 106]. Thus, cases of African tick-bite fever often occur as grouped cases among subjects entering the bush (safari, raid adventure...) and people can suffer several tick bites simultaneously [62].

The role of vertebrates as reservoirs of rickettsiae is still discussed. In natural vertebrate hosts, infections could result in a rickettsiemia, which enables new lines of uninfected ticks to become infected and for the natural cycle to be perpetuated. However, vertebrates may be rickettsemic for only short periods. In southern Zimbabwe, an endemic area for $R$. africae infection, almost $100 \%$ of cattle were found to have antibodies to SFG rickettsiae. Infection models showed mild clinical manifestations including regional lymphadenopathy, dermal erythema, edema, and tenderness at the inoculation site. Rickettsiemia was detectable for at least 32 days post infection, suggesting that cattle could serve as reservoirs for R. africae [67]. Other experiments showed that infection was transmissible to goats through tick-bite, but led to asymptomatic infection and short term rickettsiemia [68]. 


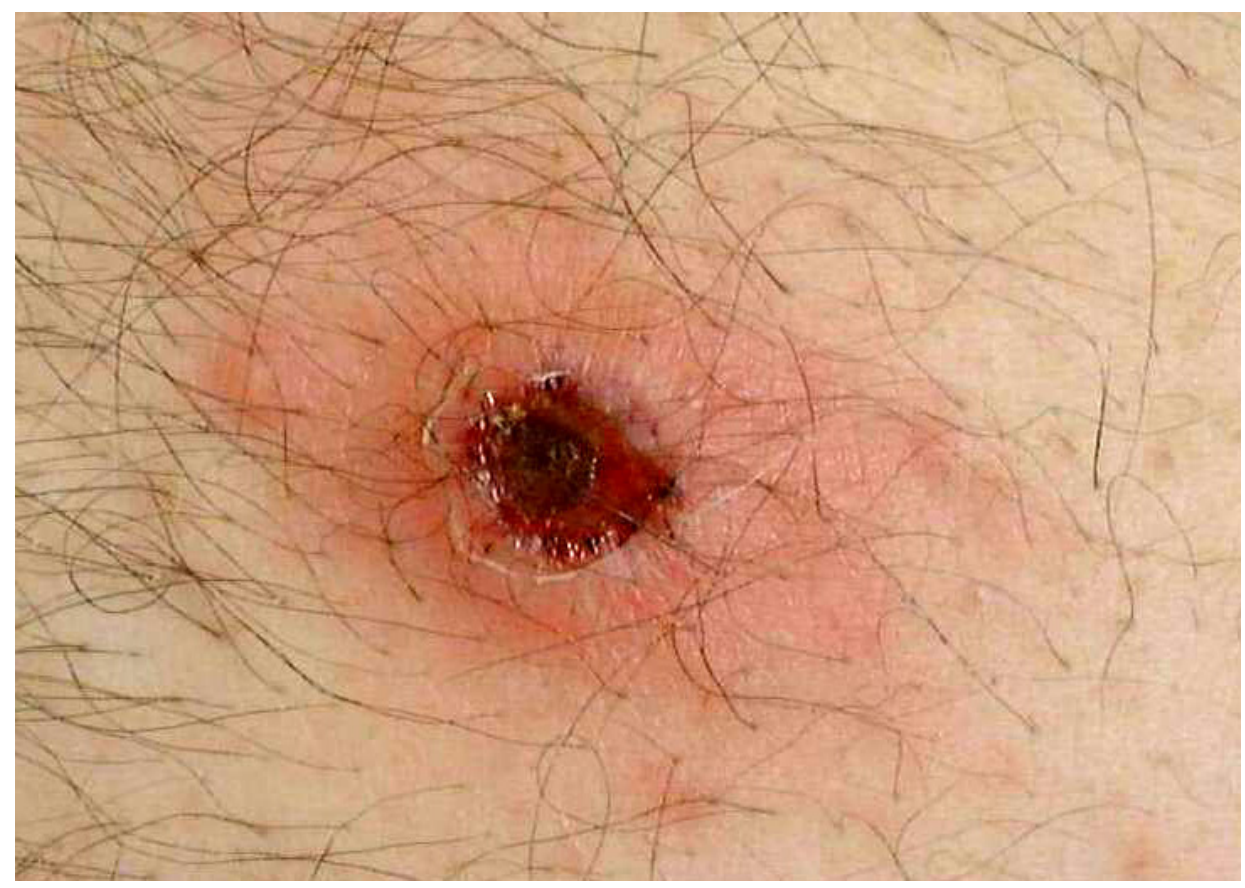

Figure 1. Inoculation eschar (tache noire) at the tick- or flea-bite site, a typical sign of spotted fever group rickettsioses. Note that it may, however, be absent (i.e. Rocky Mountain Spotted fever due to $R$. rickettsii in America is not associated with eschar).

Each stage of the ixodid tick feeds only once. As a consequence, transstadial transmission (i.e. passage of bacteria from one stage to another, from larvae to nymphs and adults) is a necessary component for vectorial competence. A rickettsia acquired by a tick during feeding on a rickettsiemic animal can then only be transmitted to another host when the tick has moulted to its next developmental stage [105]. When rickettsiae are transmitted efficiently both transstadially and transovarially (from one generation to the next via the female ovaries) in a tick species, the tick will also be a reservoir of the bacteria; the distribution of the disease caused by the bacteria will then be identical to that of its tick host [105]. Efficient transovarial transmission has been demonstrated for some species of SFG rickettsiae (but not all), including some of the currently recognized emerging pathogens such as $R$. slovaca [123], $R$. africae [66], and $R$. parkeri [53], and the suspected pathogen $R$. helvetica [25]. Interestingly, some tick-borne rickettsiae may have a deleterious effect on their vectors [94]. Many questions remain unresolved concerning the ecoepidemiology and life cycle of many tick-borne rickettsiae.

The clinical symptoms of spotted fever group rickettsioses generally begin 6-10 days after the arthropod bite and typically include fever, headache, muscle pain, rash, local lymphadenopathy, and a characteristic inoculation eschar ("tache noire") at the bite site (Fig. 1) [117]. However, the main clinical signs vary depending on the rickettsial species involved, and may allow for distinction between several SFG rickettsiosis occurring in the same location. For example, African tick bite fever is characterized by the high frequency of multiple 
inoculation eschars and grouped cases. This is due to the fact that numerous highly infected Amblyomma ticks may attack and bite many people in several places at the same time [62]. In contrast, in cases of Mediterranean spotted fever due to $R$. conorii, a single eschar is usually due to the low affinity of the tick to bite people and a low rate of infection of the ticks [117]. The details of emerging pathogen characteristics are presented in Table I. Tick-borne SFG rickettsioses range from mild to severe and fatal disease. To date, no mortalities or severe complications have been reported in patients with African tick-bite fever caused by $R$. africae [62], whereas severe disease, including one fatal case, has been reported with Japanese spotted fever rickettsioses $[6,71,72,84]$.

\subsection{Flea-borne spotted fever}

Flea-borne spotted fever (also called cat flea typhus) is an emerging disease due to Rickettsia felis, which is incompletely described. This rickettsia was probably first detected in cat fleas Ctenocephalides felis in 1918 [138]. It was rediscovered in 1990 when a Rickettsia-like organism was observed by electron microscopy in midgut epithelial cells of $C$. felis in the USA [1]. This bacterium was characterized by molecular biology techniques and named the ELB agent for the EL Laboratory (Soquel, CA, USA). In 1994, ELB agent DNA fragments were detected in blood samples obtained from a patient from Texas in 1991 [134]. In 1994 and 1995, isolation of the ELB agent was reported [115] and the name Rickettsia felis was proposed [59]. Unfortunately, contamination with $R$. typhi has hampered subsequent work. The definitive cultivation and characterization of the ELB agent was achieved in 2001 [120]. Particularly, we showed that this rickettsia can be cultivated at low temperature only [120]. We suggested that discrepancies with previously reported phenotypic findings may have resulted from contamination of $R$. felis cultures, which was reported after experi- ments by the group that provided the first description of R. felis [120]. The ELB agent was definitely characterized as a unique spotted fever group rickettsia, and finally the name $R$. felis was validated $[19,76]$.

More arguments on the pathogenicity of R. felis for humans were provided in 2000 in Mexico, when three patients with fever, exanthem, headache, and central-nervoussystem involvement were diagnosed with $R$. felis infection by specific PCR of blood or skin and seroconversion to rickettsial antigens [158]. Since then, we found high antibody titers to $R$. felis in two French patients with clinical rickettsial disease and 2 of 16 Brazilian patients with febrile rash [120]. Moreover, we identified specific sequences of $R$. felis in the serum of one Brazilian patient [120]. In 2002, two cases of typical spotted fevers were reported in an adult couple in Germany [125]. Clinical features included fever, marked fatigue, headache, generalized maculopapular rash and a single black, crusted, cutaneous lesion surrounded by a halo (on the woman's right thigh and the man's abdomen). The man had enlarged, painful lymph nodes in the inguinal region. Serologic techniques discriminated $R$. felis infection among several rickettsiae for the woman and this was confirmed by detection of $R$. felis DNA in the woman's sera. Although no laboratory evidence of $R$. felis infection was obtained for the man, the simultaneous occurrence of symptoms similar to those observed in his wife strongly suggests infection with the same microorganism [125]. Finally, we recently reported the first case of $R$. felis infection documented by serology in Asia [107]. Rash and/or eschar (6/8) have been reported in the few documented cases $R$. felis has also been recently detected in fleas in Brazil [98], Ethiopia [120], Spain [85], France [130], the United Kingdom [70], Thailand [109] and New Zealand [69]. To date, three species of fleas have been associated with $R$. felis including $C$. felis [8, 85, 98, 109, 130], C. canis [109], and Pulex irritans [8]. Transovarial transmission of 
Table I. Characteristics of emerging tick-borne spotted fever rickettsioses (1984-2004).

\begin{tabular}{|c|c|c|c|c|c|c|}
\hline Rickettsia & $\begin{array}{c}\text { Disease } \\
\text { (first clinical } \\
\text { description) }\end{array}$ & Main vector(s) & $\begin{array}{l}\text { First } \\
\text { identification } \\
\text { in ticks }\end{array}$ & $\begin{array}{c}\text { First } \\
\text { documentation } \\
\text { of human cases }\end{array}$ & $\begin{array}{l}\text { Geographic } \\
\text { distribution }\end{array}$ & $\begin{array}{l}\text { Specific clinical and epidemiological } \\
\text { characteristics }\end{array}$ \\
\hline$R$. japonica & $\begin{array}{l}\text { Oriental or } \\
\text { Japanese spotted } \\
\text { fever (1984) }\end{array}$ & $\begin{array}{c}{\text { Ixodes } \text { ovatus }^{b}} \\
\text { Dermacentor taiwanensis }^{b} \\
\text { Haemaphysalis longicornis }^{b} \\
\text { Ha. flava }^{b}\end{array}$ & 1996 & $1985^{\mathrm{c}}$ & Japan & $\begin{array}{l}\text { Rural. Agricultural activities, bamboo cutting. } \\
\text { April to October. Eschar }(91 \%) \text { and rash }(100 \%) \text {. } \\
\text { May be severe. One fatal case reported. }\end{array}$ \\
\hline $\begin{array}{l}\text { "R. conorii } \\
\text { caspia" }\end{array}$ & $\begin{array}{l}\text { Astrakhan fever } \\
\text { (1970's) }\end{array}$ & $\begin{array}{l}\text { Rhipicephalus sanguineus }^{b} \\
\text { Rh. pumilio }^{b}\end{array}$ & 1992 & $1991^{\mathrm{c}}$ & $\begin{array}{c}\text { Astrakhan, Kosovo a, } \\
\text { Chad }\end{array}$ & $\begin{array}{l}\text { Rural. Eschar 23\%. Maculopapular rash (94\%). } \\
\text { Conjunctivitis 34\%. }\end{array}$ \\
\hline R. africae & $\begin{array}{l}\text { African tick-bite } \\
\text { fever (1934) }\end{array}$ & $\begin{array}{l}\text { Amblyomma hebraeum } \\
\text { Am. variegatum }\end{array}$ & 1990 & $\begin{array}{l}\text { Preliminary data } \\
\text { in 1930's, } \\
\text { definitely in } \\
1992^{\mathrm{c}}\end{array}$ & $\begin{array}{l}\text { SubSaharan Africa } \\
\text { Reunion Island } \\
\text { (Indian Ocean) } \\
\text { West Indies }\end{array}$ & $\begin{array}{l}\text { Rural disease (safari, Ecotourism, Ecochallenges...). } \\
\text { Outbreaks and clustered cases } 74 \% \text {. Fever } 88 \% \text {. } \\
\text { Eschars: } 95 \% \text { (54\% multiple). Rash }(49 \%) \text { : } \\
\text { maculopapular or vesicular (50\%) Regional nodes } \\
43 \% \text {. No fatal case reported. }\end{array}$ \\
\hline R. honei & $\begin{array}{l}\text { Flinders island } \\
\text { spotted fever } \\
\quad(1991)\end{array}$ & $\begin{array}{l}\text { Bothriocroton (Aponomma) } \\
\text { hydrosauri }\end{array}$ & 1993 & $1992^{\mathrm{c}}$ & $\begin{array}{l}\text { Flinders island and } \\
\text { Tasmania (Australia) } \\
\text { Texas (USA) }\end{array}$ & $\begin{array}{l}\text { Rural. Peak in December and January. Rash (85\%) } \\
\text { with } 8 \% \text { purpuric. Eschar 25\%. Nodes 55\%. }\end{array}$ \\
\hline & & $\begin{array}{l}\text { Am. cajennense } e^{b} \\
\text { I. } \text { granulatus }^{b}\end{array}$ & $\begin{array}{l}1998 \\
2001\end{array}$ & & Thailand $^{\mathrm{a}}$ & \\
\hline $\begin{array}{l}\text { "R. sibirica } \\
\text { mongolotimonae" }\end{array}$ & Unnamed (1996) & $\begin{array}{l}\text { Hyalomma asiaticum } \\
\text { Hy. } \text { truncatum }^{b}\end{array}$ & 1991 & $1996^{\mathrm{c}}$ & $\begin{array}{l}\text { Inner Mongolia } \\
\text { (China) }^{\mathrm{a}} \text { Africa } \\
\text { Southern France }^{\mathrm{a}}\end{array}$ & $\begin{array}{c}\text { Cases described in southern France between March } \\
\text { and July (7) and South Africa (1). Eschar (6/8), } \\
\text { rash (5/8) and lymphangitis (2/8). }\end{array}$ \\
\hline R. slovaca & $\begin{array}{c}\text { TIBOLA } \\
\text { DEBONEL (1997) }\end{array}$ & $\begin{array}{l}\text { D. marginatus } \\
\text { D. reticulatus }\end{array}$ & 1968 & $1997^{d}, 2003^{c}$ & Europe & $\begin{array}{l}\text { Fever and Rash rare. Typical eschar on the scalp } \\
\text { with cervical nodes. Mild. }\end{array}$ \\
\hline R. helvetica & Unnamed (1999) & $\begin{array}{l}\text { I. ricinus } \\
\text { I. } \text { ovatus }^{b} \\
\text { I. persulcatus } b \\
\text { I. } \text { monospinus }^{b}\end{array}$ & $\begin{array}{l}1979 \\
2002\end{array}$ & $\begin{array}{l}1999^{\mathrm{e}}, 2000^{\mathrm{d}} \\
2003^{\mathrm{d}}\end{array}$ & $\begin{array}{l}\text { Europe, Japana, } \\
\text { Thailand }\end{array}$ & $\begin{array}{l}\text { Incompletely described. Fatal perimyocarditis and } \\
\text { sarcoidosis related to } R \text {. helvetica infection have } \\
\text { been reported, but discussed. Few cases } \\
\text { documented by serology only in France and in } \\
\text { Thailand. Rash and eschar seems to be rare. }\end{array}$ \\
\hline R. heilongjiangensis & Unnamed (1992) & D. silvarum & 1982 & $1992,1996^{\mathrm{c}}$ & Northeastern China & Rash, eschar, and nodes. No fatal case reported. \\
\hline R. aeschlimannii & Unnamed (2002) & $\begin{array}{l}\text { Hyalomma marginatum } \\
\text { marginatum } \\
\text { H. m. rufipes } \\
\text { Rh. appendiculatus }\end{array}$ & 1997 & $2002^{\mathrm{e}}$ & $\begin{array}{l}\text { Southern Europe } \\
\text { Africa }\end{array}$ & $\begin{array}{l}\text { Eschar and maculopapular rash (1 case) } \\
\text { Eschar (1 case) }\end{array}$ \\
\hline R. parkeri & Unnamed (2004) & Am. maculatum & 1939 & $2004^{\mathrm{c}}$ & South Central USA & One case reported: fever, multiple eschars and rash. \\
\hline
\end{tabular}

${ }^{\text {a }}$ Detection from tick only. ${ }^{\mathrm{b}}$ Although the rickettsia has been detected or/and isolated in this tick, its role as a vector has not been definitely proven. ${ }^{\mathrm{c}}$ Documentation by culture; ${ }^{\mathrm{d}}$ Documentation by serology; ${ }^{\mathrm{e}}$ Documentation by molecular tools. Note that the pathogenicity of $R$. helvetica has yet to be definitely confirmed. TIBOLA for "tick-borne lymphadenopathy". DEBONEL for "Dermacentor-borne-necrosis-erythemalymphadenopathy". 
$R$. felis in fleas has also been reported, suggesting that fleas could act as reservoirs of the rickettsia [8]. All these data suggest that $R$. felis infection may be endemic worldwide. The role of mammals, particularly cats and dogs, in the life cycle and circulation of $R$. felis, requires exploration.

\subsection{Specific diagnosis procedures}

The specific methods for the diagnosis of rickettsioses were reviewed a few years ago [75]. Serologic tests are the most valuable tools while immunofluorescence is currently considered as the reference method. One limitation of serology is the cross-reactivity that might occur between the antigens of organisms within the same genus and in different genera [105]. Thus, serology should only be considered as the first step towards diagnosing a rickettsial disease, particularly if no rickettsiae has ever been isolated or detected in the area. This will prevent mistakes being made when "emergence" of tick-borne diseases are described. In order to differentiate infections within rickettsial antigens, difference in dilution as well as cross-absorption of sera and Western-blotting can be done when cross reaction is suspected [75, 107]. Isolation in cell cultures, particularly using the shell vial technique remains the ultimate diagnostic method but is only available in biosafety level 3 laboratories [75, 148]. Polymerase chain reaction (PCR) and sequencing methods are now readily used to detect and identify rickettsiae in blood and skin biopsies (particularly the eschar). Ticks and fleas may also be used as epidemiological tools to detect the presence of a pathogen in a specific area, leading sometimes to detect rickettsiae of unknown pathogenicity [105, 130]. We recently proposed a nested PCR assay, named "suicide PCR", which uses single-use primers targeting a gene never amplified previously in the laboratory. Such a procedure avoids "vertical" contamination by amplicons from previous assays, one of the limitations of extensive use of $\mathrm{PCR}$, and does not require a positive con- trol. This technique has been successful with EDTA-blood, serum, and lymph node specimens, in the diagnosis of African tick bite fever and infection due to $R$. slovaca $[119,122]$. This technique was also applied in our laboratory to DNA from 103 skin biopsies from patients with confirmed rickettsiosis, 109 skin biopsies from patients who possibly had a rickettsiosis, and 50 skin biopsies from patients with no rickettsial disease. Specificity was $100 \%$. Sensitivity $(68 \%)$ was 2.2 times higher than culture and 1.5 times higher than regular PCR [50].

\subsection{Treatment}

Early empiric antibiotic therapy should be prescribed in any suspected tick-transmitted rickettsiosis, before confirmation of the diagnosis. Doxycycline (200 mg per day) remains the treatment of choice for tick- and flea- transmitted SFG rickettsioses, including in children [60, 87, 114, 117]. In cases of allergy to tetracyclines, chloramphenicol or josamycin (a macrolide not available in the USA) may be administered. Fluoroquinolones and newer macrolides may also be used [28, 129, 135]. In pregnant women, josamycin or newer macrolides can be used. In patients with severe disease, doxycycline should be administered intravenously up to $24 \mathrm{~h}$ after apyrexia. The exact treatment duration is not fully determined. Usually, therapy should be prescribed for up to 2 or 3 days after the patient's fever has abated. The use of corticosteroids in severe forms is controversial [71].

\section{HUMAN EHRLICHIOSES AND ANAPLASMOSES}

Ehrlichioses and anaplasmoses are caused by bacteria within the family Anaplasmataceae. These diseases have been known for a long time in veterinary medicine [127]. However, in recent years, three bacteria have been recognized as emerging tick-borne pathogens in humans: (i) human monocytic 


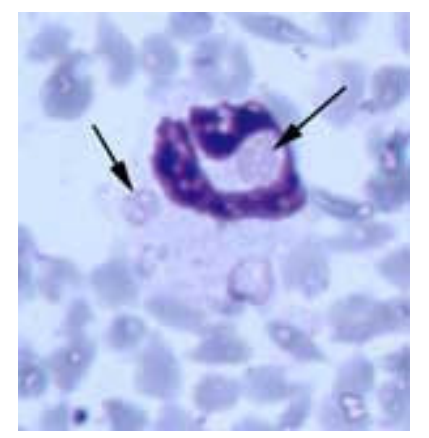

Figure 2. Multiple morulae consistent with Ehrlichia ewingii in a neutrophil (Giemsa stain, 100×). Reprinted from [156].

ehrlichiosis due to Ehrlichia chaffeensis, (ii) Ehrlichia ewingii granulocytic ehrlichiosis, and (iii) human granulocytic anaplasmosis (formerly human granulocytic ehrlichiosis) due to A. phagocytophilum (formerly named the HGE agent, E. phagocytophila and E. equi) [37] (Tab. II). Ehrlichioses and anaplasmoses are tick-borne zoonoses, the causative agents being maintained through enzootic cycles between ticks and animals. To date, transovarial transmission of these agents in ticks appears to be inefficient. Thus, mammals are presumed to play a major role in the maintenance and propagation of these bacteria in nature. Various infectious syndromes have been described in animal species [31] (Tab. II). In vivo, these bacteria mainly infect the cells of bone marrow origin, in particular leucocytes where they occur within membranebound vacuoles. The intraphagosomal bacteria divide by binary fission to produce a typical cluster of organisms called a morula (Fig. 2). The interaction between members of Anaplasmataceae and the targeted cells have been illustrated recently $[102,128]$.

\subsection{Human monocytic ehrlichiosis}

The first HME case was described in 1986, when the examination of a peripheral blood smear of a severely ill man yielded intracytoplasmic inclusions in several of the monocytes. The patient had been bitten by ticks in Arkansas. This case was first assumed to be due to Ehrlichia canis, the agent of monocytic canine ehrlichiosis [81], but the causative agent of HME, Ehrlichia chaffeensis, was isolated in 1991 in the USA [34]. Since that time, several hundred cases have been reported. Since a major review on Ehrlichia chaffeensis, was recently published, we refer the reader to this major paper for details [102].

E. chaffeensis is maintained in nature as a complex zoonosis, potentially involving many vertebrates serving as reservoirs for the bacterium and/or blood meal sources for tick vectors. Amblyomma americanum, the Lone Star tick, is the primary vector of E. chaffeensis [4]. In the USA, this tick is distributed in south central, southeastern and mid-Atlantic USA. It usually inhabits meadows, woodlands and hardwood forests. Its primary hosts are diverse wild and domestic mammals, although deer are considered to be definitive hosts (hosts upon which the reproductive stage depends). All stages of A. americanum readily bite people. Adult and nymph activity peaks from April through June and decreases as the summer progresses. Larvae are active through November. E. chaffeensis has been detected in A. americanum ticks collected from 14 states and molecular prevalence was found to vary between $5-15 \%$, with a lower prevalence appearing within nymphs than adults [41, 102]. The tick-bacteria association is, however, poorly known. Although transstadial transmission of E. chaffeensis is known to occur in A. americanum, there is no data supporting transovarial transmission and the absence of transovarial transmission has been demonstrated in laboratory models [79]. Although PCR has been used to detect $E$. chaffeensis in other tick species in the USA, their role as a vector has not been demonstrated [102].

To date, the white-tailed deer (Odocoileus virginianus) is the sole recognized efficient reservoir of E. chaffeensis. Evidence is based 
on seroprevalence studies, molecular detection and isolation of E. chaffeensis, as well as experimental transmission studies. Bacteremia has been demonstrated to persist up to months after infections [102]. Experimental transmission has also been demonstrated in domestic dogs (Canis familiaris), presenting mild to unapparent disease, and the red fox (Vulpes vulpes). Domestic dogs and wolves (C. lupus) are considered as potential reservoirs because of their numbers, their tick parasitism and the close contact to humans, and their susceptibility to E. chaffeensis. Domestic goats were also found to be infected in a single report with a longterm bacteremia [102]. Although serologic (in the raccoon (Procyon lotor), whitefooted mouse (Peromyscus leucopus) and Virginia opossum (Didelphis virginiana)) or molecular (in coyote (Canis latrans)) evidence of infection has been reported in other mammals, the role of these mammals as efficient reservoirs has yet to be demonstrated [102].

From 1986 to 1997 , more than 700 presumptive cases were reported to the CDC [102]. Data accumulated during the first five years (1997-2001) of national surveillance for human ehrlichioses and anaplasmoses have recently been reported [52]. During this period, 503 cases of HME were reported, including 338 confirmed cases reported from 23 states. Most HME cases were reported from south-central and southeastern USA. There, the tick vector $A$. americanum reaches its highest population and human exposure is the greatest [102]. HME is a seasonal disease and incidence is correlated with tick activity, particularly in nymphs and adults. Although HME has been reported during March through November, most of the cases occur during May through July. Reports of HME occurring in the late fall and winter are unusual but may occur particularly in southern states [52, 102]. The states with the highest average annual incidence of HME were Arkansas (6.2 cases per million population), Missouri ( 5.2 cases per million population) where the largest absolute number of cases was reported $(n=140)$, Oklahoma (4.3 cases per million population), and Tennessee ( 2.5 cases per million population). Sporadic cases have been reported in the East Coast, most notably along the Mid-Atlantic coast plain [52, 102]. However, differences between the results of passive and active surveillance have been discussed. In general, incidence based on active surveillance has been estimated to be 10 -fold higher than the highest rates reported by individual states for passive surveillance [102]. For example, a prospective study in Cape Girardeau, Missouri and surrounding counties in southeast Missouri and southwestern Illinois was conducted during a 3-year period (1997-1999). A total of 102 febrile patients with tickexposure were enrolled during this period, and $29(28.4 \%)$ of them had either definite or probable HME. As expected, all cases occurred between April and mid-August, including 16 (56\%) in July. For 1997, 1998, and 1999, the calculated incidence for HME was 2, 4.7, and 3 per 100000 population, respectively (incidence calculations were based on the total population of all counties where the patients lived). According to the authors, HME was even probably underestimated in this prospective study throughout the rural southeastern and south central states. In this particular disease-endemic area, case-patients were identified mainly in one primary care-based physician's office that cares for a population base of approximately 7000 persons. Therefore, the real incidence of HME is likely to be higher in Cape Girardeau and surrounding counties [97].

Tick-bite or tick-exposure is a common finding in patients with HME, but this feature is lacking in $10-30 \%$ of the cases. The incubation period is 1 to 2 weeks (median 9 days). Among the 29 cases reported above in Missouri, a tick bite was documented in 21 case-patients $(72 \%)$, and tick exposure without a tick bite in 8 case-patients $(28 \%)$ [97]. For all case-patients, tick attachment ranged from 24 to $72 \mathrm{~h}$, except for one casepatient who experienced tick attachment for $12 \mathrm{~h}$. The incubation period from the 
Table II. The agents of emerging human ehrlichioses and anaplasmoses.

\begin{tabular}{|c|c|c|c|c|c|c|}
\hline $\begin{array}{l}\text { Bacteria } \\
\text { (year of cultivation) }\end{array}$ & $\begin{array}{l}\text { Typical cell } \\
\text { tropism }\end{array}$ & Main vector(s) & $\begin{array}{l}\text { Animals found } \\
\text { to be infected }\end{array}$ & $\begin{array}{l}\text { Related diseases } \\
\text { (year of recognition) }\end{array}$ & Symptoms and common laboratory findings & Geographic area \\
\hline \multirow[t]{6}{*}{$\begin{array}{l}\text { Ehrlichia chaffeensis } \\
\text { (1991) }\end{array}$} & \multirow[t]{6}{*}{ Monocytes } & \multirow[t]{6}{*}{$\begin{array}{l}\text { Amblyomma } \\
\text { americanum }\end{array}$} & Human & $\begin{array}{l}\text { Human monocytic } \\
\text { ehrlichiosis (1987) }\end{array}$ & $\begin{array}{l}\text { Fever, headache, myalgia, vomiting, and less frequently rash, } \\
\text { cough, and neurologic manifestations. Leucopenia } \\
\text { Thrombocytopenia. May be severe }\end{array}$ & $\begin{array}{l}\text { South-central and South- } \\
\text { eastern USA. Sporadic cases } \\
\text { along the Atlantic Coast plain }\end{array}$ \\
\hline & & & White-tailed deer & - & $\begin{array}{l}\text { Molecular detection (1997), isolation (1997) and animal models } \\
\text { (2001). Potential reservoir }\end{array}$ & $\begin{array}{l}\text { South-central and South- } \\
\text { eastern USA }\end{array}$ \\
\hline & & & Dogs & - & Mild to unapparent disease & Virginia, Oklahoma, USA \\
\hline & & & Goats & - & $\begin{array}{l}\text { Isolation (2000). Susceptibility or role as efficient reservoir: } \\
\text { unknown }\end{array}$ & Georgia \\
\hline & & & Coyote & - & $\begin{array}{l}\text { Molecular detection and serology (2000). Susceptibility or role } \\
\text { as efficient reservoir: unknown }\end{array}$ & Oklahoma, USA \\
\hline & & & $\begin{array}{l}\text { Raccoon, white- } \\
\text { footed mouse, } \\
\text { Virginia possum }\end{array}$ & - & Serological evidence & Various settings in the USA \\
\hline \multirow[t]{3}{*}{$\begin{array}{l}\text { E. ewingii } \\
\text { (1992) }\end{array}$} & \multirow[t]{3}{*}{$\begin{array}{l}\text { Neutrophilc } \\
\text { granulocytes }\end{array}$} & \multirow[t]{3}{*}{ A. americanum } & Dogs & $\begin{array}{l}\text { Canine granulocytic } \\
\text { ehrlichiosis } \\
\text { (1971) }\end{array}$ & $\begin{array}{l}\text { Fever and lameness, and/or neutrophilic polyarthritis and/or } \\
\text { neurologic abnormalities. Mild-to-moderate thrombocytopenia } \\
\text { Reactive lymphocytes }\end{array}$ & $\begin{array}{l}\text { South eastern and south } \\
\text { central USA }\end{array}$ \\
\hline & & & Human & $\begin{array}{l}\text { E. ewingiigranulocytic } \\
\text { ehrlichiosis (1999) }\end{array}$ & $\begin{array}{l}\text { Fever, headache, thrombocytopenia, with or without leucopenia } \\
7 / 8 \text { cases seen in immunocompromised patients }\end{array}$ & $\begin{array}{l}\text { a USA: Missouri, Oklahoma } \\
\text { and Tennessee }\end{array}$ \\
\hline & & & $\begin{array}{l}\text { White-tailed } \\
\text { deer }\end{array}$ & $\begin{array}{l}\text { Molecular detection } \\
\text { and animal models } \\
(2002)\end{array}$ & Not described & $\begin{array}{l}\text { USA: Kentucky, Georgia, } \\
\text { and South Carolina }\end{array}$ \\
\hline
\end{tabular}


Table II. Continued.

\begin{tabular}{|c|c|c|c|c|c|c|}
\hline $\begin{array}{l}\text { Bacteria } \\
\text { (year of cultivation) }\end{array}$ & $\begin{array}{l}\text { Typical cell } \\
\text { tropism }\end{array}$ & Main vector(s) & $\begin{array}{l}\text { Animals found } \\
\text { to be infected }\end{array}$ & $\begin{array}{l}\text { Related diseases } \\
\text { (year of recognition) }\end{array}$ & Symptoms and common laboratory findings & Geographic area \\
\hline \multirow{14}{*}{$\begin{array}{l}\text { Anaplasma } \\
\text { phagocytophilum } \\
\text { (1999) } \\
\text { (formerly Ehrlichia } \\
\text { phagocytophila, E. equi, } \\
\text { and HGE agent) }\end{array}$} & \multirow{14}{*}{$\begin{array}{l}\text { Neutrophilc } \\
\text { granulocytes }\end{array}$} & \multirow{14}{*}{$\begin{array}{l}\text { USA: } \\
\text { Ixodes scapularis } \\
\text { I. pacificus } \\
\text { Europe: I. ricinus }\end{array}$} & Cattle, sheeps, goats & $\begin{array}{l}\text { Tick-borne fever } \\
\text { (1932) }\end{array}$ & $\begin{array}{l}\text { High fever, decrease in milk production, and possibly } \\
\text { anorexia, depression, cough, nasal discharge, diarrhea, } \\
\text { abortion, mastitis }\end{array}$ & Northern and central Europe \\
\hline & & & & & & \\
\hline & & & Equines & $\begin{array}{l}\text { Equine granulocytic } \\
\text { ehrlichiosis (1969) }\end{array}$ & $\begin{array}{l}\text { Fever, and/or depression, anorexia, lower limb oedema, } \\
\text { petechiae, icterius, ataxia, or reluctance to move }\end{array}$ & $\begin{array}{l}\text { USA: Northeastern and North } \\
\text { central regions; West Coast. } \\
\text { Northern and central Europe }\end{array}$ \\
\hline & & & Human & $\begin{array}{l}\text { Human anaplasmosis } \\
\text { (1994 USA; } 1997 \\
\text { Europe) }\end{array}$ & $\begin{array}{l}\text { Sndifferentiated febrile illness occurring in summer or } \\
\text { spring Anorexia, arthralgies, nausea, cough, atypical } \\
\text { pneumonitis } \\
\text { Leucopenia. Thrombocytopenia. May be severe }\end{array}$ & $\begin{array}{l}\text { USA (most cases in north eastern } \\
\text { and upper mid-western regions } \\
\text { of the USA; less frequently in } \\
\text { Northern California). } \\
\text { Northern and central Europe }\end{array}$ \\
\hline & & & Dogs & Unnamed (1995) & $\begin{array}{l}\text { Mild to unapparent disease (experimental models). } \\
\text { Fever, lethargy and thrombocytopenia (natural infection) }\end{array}$ & Northern and central Europe \\
\hline & & & Cats & $\begin{array}{l}\text { Feline granulocytic } \\
\text { ehrlichiosis (1997) }\end{array}$ & $\begin{array}{l}\text { Fever, lethargy, anorexia, tachypnea. Neutrophilia, } \\
\text { lymphopenia }\end{array}$ & Sweden \\
\hline & & & White-footed mouse & - & Not described. Potential reservoir in the USA (1997) & Eastern and mid western USA \\
\hline & & & White-tailed deer & - & Not described. Potential reservoir (1996) & Eastern and mid western USA \\
\hline & & & Cottontail rabbits & - & $\begin{array}{l}\text { Not described. Enzootic cycle with } I \text {. dentatus ticks } \\
\text { (2003) }\end{array}$ & USA \\
\hline & & & $\begin{array}{l}\text { Small mammals } \\
\text { (mice, shrew, vole) }\end{array}$ & - & $\begin{array}{l}\text { Not described. Enzootic cycle involving I. trianguliceps } \\
\text { and woodland vole described in Great Britain (2000) }\end{array}$ & Europe \\
\hline & & & Roe deer & - & $\begin{array}{l}\text { Not well characterized Molecular evidence of infection } \\
\text { (2001) }\end{array}$ & $\begin{array}{l}\text { Spain, Austria, Norway and the } \\
\text { Czech Republic }\end{array}$ \\
\hline & & & Wild boars & - & Not described. Molecular evidence of infection (2003) & Czech Republic \\
\hline & & & Foxes & - & Not described. Molecular evidence of infection (2003) & Austria \\
\hline & & & Birds & - & Not described. Molecular evidence of infection (2003) & USA, Europe \\
\hline
\end{tabular}


observed tick bite until the onset of illness ranged from 1 to 4 weeks.

HME appears as an undifferentiated febrile illness. The main clinical signs include fever $(98 \%)$, headache $(77 \%)$, myalgias $(65 \%)$, vomiting $(36 \%)$, rash $(35 \%)$ including petecchiae, macular, maculopapular or diffuse erythema, cough $(25 \%)$, neurologic findings and mental status changes (20\%) [102]. Malaise (30 to $80 \%$ ) as well as various manifestations including lymphadenopathy, gastrointestinal symptoms, pharyngitis or less frequently, conjunctivitis, dysuria, and peripheral edema may occur [102]. Leukopenia, thrombocytopenia, and elevated hepatic transaminase levels are the most common laboratory findings. Hospitalization is required in more than half of the cases and case-fatality rate has been estimated at $3.1 \%$ [102]. HME is most commonly diagnosed in adults more than 50 years old [52, 102]. Although age has appeared in some studies as an independent risk factor for severe or fatal HME, many severe or fatal cases have been described in apparently healthy children or young adults. Severe or fatal HME has also been reported in immunocompromised patients [102]. Asymptomatic infection may occur based on serologic evidence [102]. Finally, since A. americanum is also the vector of other tickborne agents, co-infection may occur [136].

\subsection{Ehrlichia ewingii granulocytic ehrlichiosis}

Ehrlichia ewingii was recognized in 1992 as the agent of canine granulocytic ehrlichiosis [3], a disease that had been first described in a dog in 1971 in Arkansas [40]. Thereafter the disease was described in several other states in south eastern and south central USA where the recognized vector is the Lone Star tick, Amblyomma americanum (see human monocytic ehrlichiosis for details on this tick) $[5,31]$. Field-collected ticks from North Carolina were recently tested and the infection rates for E. ewingii were low ( $<1 \%$ in adults), with a minimum infection rate for the nymphs at $0.4 \%$ (5 of
1308 ticks) [155]. In a recent series of 15 dogs confirmed to have E. ewingii infection by molecular tools, clinical signs included fever and lameness, and/or neutrophilic polyarthritis and/or unexplained ataxia, paresis or other neurologic abnormalities [56], but asymptomatic infection was found in three dogs [56]. Laboratory findings included thrombocytopenia (all dogs), reactive lymphocytes (five dogs). Morulae consistent with $E$. ewingii infection were identified in neutrophils in 8 dogs. However, identification of granulocytic morulae does not differentiate infections due to $E$. ewingii from infections due to Anaplasma phagocytophilum that may occur in dogs [31]. Infection with E. ewingii has been reported in $6.2 \%$ $15.8 \%$ of dogs from southeastern Virginia, Oklahoma, and southeastern North Carolina. Recently, by combining data from PCR testing and experimental infection studies in fawns, at least 8 of 110 white-tailed deer (7.3\%) from Kentucky, Georgia, and South Carolina were shown to be infected with E. ewingii (Fig. 2). These data raised the question of white-tailed deer as a potential reservoir for E. ewingii [156].

Human infections with $E$. ewingii were first reported in 1999, when blood samples collected in Missouri from 1994-1998 from 413 patients with possible ehrlichiosis were retrospectively analyzed [24]. Four tickexposed patients were shown to be infected with E. ewingii by molecular tools. Furthermore, morulae were seen in neutrophils from two of them. Clinical signs included fever, headache, thrombocytopenia, with or without leucopenia. Three of these patients had underlying diseases and were receiving immunosuppressive therapy [24]. More recently, four cases were reported in male HIV infected patients from Oklahoma and Tennessee [103]. The cases were confirmed by molecular tools (4/4) and morulae in granulocytes were found in one patient out of the two examined. Three were receiving highly active antiretroviral therapy and the median CD4+ cell count was 176/ $\mu \mathrm{L}$ (range, 106-226). The main clinical signs included fever (4/4), malaise and myalgia (2/4), 
headache (1/4), nausea and vomiting (1/4). Leukopenia, thrombopenia and anemia were respectively seen in $3 / 4$ patients. Other laboratory findings included an elevated aspartate aminotransferase level (2/4), elevated alanine aminotransferase level (1/4), and hyponatremia (1/4). Two patients were hospitalized and no fatal case was reported. In the same study, 13 HIV patients infected with $E$. chaffeensis were reported and those infected with $E$. ewingii developed fewer disease manifestations and complications than did patients infected with $E$. chaffeensis. This should be interpreted carefully because of the small number of patients evaluated [103]. To date, it is still unclear whether E. ewingii causes disease primarily in immunocompromised persons or if it is responsible for illnesses in a broader patient population.

\subsection{Human granulocytic anaplasmosis (formerly human granulocytic ehrlichiosis)}

The first case of clinically recognized human granulocytic anaplasmosis was described in the USA in 1994 [30]. Then, the disease emerged in Europe in 1997 [110]. The causative organism, first named human granulocytic ehrlichia or HGE agent, was cultivated in HL 60 Cells in 1996 [55] and in tick cell culture in 1999 [91]. With the help of molecular phylogenetic studies [37], this bacteria has been unified within the single species designation Anaplasma phagocytophilum, with organisms formerly known as (i) Ehrlichia equi, known as the agent of equine granulocytic ehrlichiosis in the USA since 1969 and reported starting in the 1990's in Europe [12, 17, 133] and (ii) E. phagocytophila, known since the 1930's as the agent of tickborne fever in cattle, sheep and goats in most European countries where it may contribute to considerable productivity losses $[21,51,142]$. When infected, these animals present various febrile syndromes [21,93]. Other animals have been found to be infected with A. phagocyptophilum, including dogs and cats $[31,144]$. The target cells in the organism of $A$. phagocytophilum are neutrophils, although morulae have been described in other cells, such as the endothelium and macrophages [96].

\subsubsection{Natural history of Anaplasma phagocytophilum}

The life cycle of A. phagocytophilum is not fully understood. In the USA, Ixodes scapularis (the black-legged tick) is the principal vector of $A$. phagocytophilum [10]. It is distributed in southeastern USA, and mid and northeastern USA (where it was previously named $I$. dammini). This exophilic tick inhabits deciduous forests and maritime forests and favors humid microhabitats. In the north of the USA, adults are active from March-April through late June, then again between October and December. Nymphs are active in the late spring and summer. Larvae are active from late June through October. In the south of the USA, all stages are usually active from November through May. Primary hosts of immatures are small mammals, reptiles and birds. Adults feed on large-size mammals (deer, dog). The affinity of this tick species for biting people is high. On the contrary, I. pacificus (the western black-legged tick) is the primary vector in the Pacific coast states [10]. It is distributed from the southern Pacific coast of Canada through California, in shrub forests, coniferous forests, and deserts. Primary hosts for immature ticks are small mammals, reptiles and birds, whereas adults feed on large sized mammals. Both nymphs and adults readily bite people. Molecular detection of A. phagocytophilum in both I. scapularis and I. pacificus ticks have been regularly published in the literature in recent years [78, 105]. Although other tick species or genera such as Dermacentor spp. have been seldom shown to harbor A. phagocytophilum, their role as a vector has not been demonstrated [32].

In Europe, I. ricinus is the recognized vector of human granulocytic anaplasmosis $[18,21]$. It is prevalent from western 
Europe (with the exception of the Mediterranean area) through central Asia, in a humid microhabitat in forests, woods borders, and pastures. All stages are usually active between April and June and in the winter. During the summer, immature ticks remain active whereas adults often enter diapause until early fall. The primary hosts of immature ticks are small mammals, reptiles and birds. Occasionally, they feed on mid-size to large-size mammals. Adults feed on mid-size to large-size mammals. The affinity for biting people is high. Many molecular epidemiological studies have been conducted and published in recent years, and A. phagocytophilum has been detected in I. ricinus throughout Europe $[18,21,139]$. However, the dynamics of transmission to mammals have not been completely elucidated [95]. Coinfection of ticks with both $A$. phagocytophilum and other agents transmitted by the same tick species, such as Borrelia burgdorferi, the agent of Lyme disease are also regularly reported [32], both in the USA and Europe.

In the USA, the white-footed mouse Peromyscus leucopus and the white-tailed deer (Odocoileus virginianus), are thought to be the most important reservoirs in the eastern and mid western USA. Recently, an enzootic cycle between cottontail rabbits and their ticks, I. dentatus was demonstrated [54]. This tick has a low affinity for biting people and usually feeds on small mammals. However, as suggested by the authors, the propensity of I. dentatus to densely inhabit peridomestic sites, and their potential to be transported by birds, a cycle of transmission parallel to that of cottontail rabbits would facilitate introduction and perpetuation of $A$. phagocyptophilum [54]. In addition, a cycle involving I. spinipalpis ticks and rodents has been identified in Colorado and California [159].

In Europe, in addition to the large mammals (horses, cattle, sheep, goats, dogs, cats) described above, small mammals such as the wood mouse Apodemus sylvaticus, the yellow-necked mouse A. flavicollis, the common shrew Sorex araneus, and the bank vole Clethrionomys glareolus have been shown to harbor A. phagocytophilum in Switzerland, and have been suggested as potential reservoirs [78]. Evidence that $A$. phagocytophilum can be maintained in a system in which woodland rodents are a dominant reservoir host species has also been recently shown in Great Britain by molecular tools [20]. Both bank voles and wood mice were positive but restricted to periods of peak nymphal and adult I. trianguliceps activity. Most PCR-positive rodents were positive only once, suggesting that rodent infections are generally short-lived and that ticks rather than rodents may maintain the infection over the winter [20]. I. trianguliceps usually bites small mammals only, and rarely people [132]. However, I. trianguliceps-driven endemic cycles may provide an efficient reservoir from which $I$. ricinus may acquire infections from rodents, and transmit the bacteria to another animal including people at the next blood meal [20]. Roe deer (Capreolus capreolus) in Spain, Austria and the Czech Republic, wild boars (Sus scrofa) in the Czech Republic and foxes (Vulpes vulpes) in Austria have also been shown by molecular tools to be exposed to this bacteria $[99,111]$. Usually, genetic variants are often identified when A. phagocytophilum is detected in vectors, people or animals [86].

Interestingly, only sequences determined for part of the GroEL operon of Anaplasma sp. from wild boars in the Czech Republic were strictly identical to those detected in humans with anaplasmosis in Slovenia [111]. The role of birds in the circulation of A. phagocytophilum has also been hypothesized both in the USA and in Europe [15, 33].

\subsubsection{Epidemiological and clinical aspects}

Ten years have passed since the first patient with clinically recognized human granulocytic anaplasmosis was described 
in Minnesota, USA in 1994 [30]. From 1997 to 2001, 654 confirmed, 434 probable, and 3 suspect/unknown were reported through national surveillance from 21 continental states in which the cases resided [52]. This allows for an appreciation of the epidemiological aspects of the disease, but is limited by the quality of the surveillance system [52]. Most cases were reported from the states in the north eastern and upper mid-western regions of the USA. The states with the highest annual incidence of the disease were Connecticut (22.3 cases per million population), Minnesota (16.2 cases per million population), Rhode Island (12.7 cases per million population) and New York (4.7 cases per million population), where the largest absolute number $(n=438)$ was reported [52]. Locally high incidences occur in both Wisconsin (up to 58 cases/ 100000 ) and Connecticut (up to 52 cases/ 100000 ) (Dumler S., personal communication). A few patients have been described in California. The median age was greater than 50 years, with the highest age-specific incidence occurring among people older than 50. Human anaplasmosis is clearly a seasonal zoonosis, since most of the cases occurred between May and October, linked to the activity of the tick vectors [52]. At this period, the nymphal stage of I. scapularis, smaller and difficult to see when they attach to the human body, are active. Outdoor activities are increased during the summer, leading to an increased risk of exposure to tick-bites $[10,52]$. Human behavior in a specific setting have also been shown to influence the risk of tick bites. For example, when six different human behaviors were evaluated for acquiring I. pacificus nymphs in a deciduous woodland in California, people in contact with wood were at higher risk when compared to those exposed to leaf litter only; sitting on logs was the riskiest behavior followed by gathering wood, sitting against trees, walking, stirring and sitting on leaf litter, and just sitting on leaf litter [77].

The first documented case of human anaplasmosis in Europe was reported in Slovenia in 1997 [110]. Thereafter, seroepidemiologic surveys have found a prevalence of antibodies in a range of $0 \%-2.9 \%$ in blood donors and $1.5 \%-21 \%$ of tick-exposed people throughout northern and central Europe [18]. To date a total of 20 cases have been reported in Europe including Slovenia [7, 80], the Netherlands [147], Spain [100], Sweden $[16,64]$, Norway [14], Croatia [90], Poland [145], Italy [131], Austria [149], and France [124]. The majority of cases occurred between June and August [18]. When cases reported in 2001 were reviewed, a history of tick-bite was recalled in $67 \%$ of the cases; the median age was 38 years, and less than $20 \%$ of the patients were under the age of 20 years.

Human anaplasmosis appears most commonly as an undifferentiated febrile illness occurring in the summer or spring [96]. The incubation period following the tick-bite is 7-10 days. Symptoms include high fever, rigors, generalized myalgias, severe headache and malaise [10, 96]. Anorexia, arthralgia, nausea and a non-productive cough are frequent. A rash is rarely reported (1-11\%) and experts in the field do not consider a rash as part of the clinical picture of human anaplasmosis [10]. Leucopenia and thrombocytopenia are often seen, and less frequently anemia. Hospitalisation is required in approximately one half of the patients. The disease may be severe, particularly in the elderly, when there is concomitent chronic illnesses, a lack of recognition, or delayed specific antibiotic treatment [10]. Fatal cases have been reported in the USA, but case fatality rate has been estimated to be about $1 \%[10,102]$. In Europe, a few cases have been reported to date. However, the disease seems to be less severe than that described in the USA and no death has been reported [18]. It should also be noted that three cases showed atypical pneumonitis [124].

Finally, few patients have been shown to be coinfected with other tick-borne agents sharing the same Ixodes sp. vectors such as Lyme borreliosis and babesiosis in Europe and the USA [18, 92]. 


\subsection{Specific diagnosis procedures}

Laboratory confirmation of human monocytic ehrlichiosis and human granulocytic anaplasmosis is based on several tests that are not to date widely available for routine use. Indirect immunofluorescence serology remains the most widely available test. However, limitations include delay for seroconversion (early sera will often return negative), as well as possible false positive detection due to cross-reacting bacteria. Diagnostic procedures have been recently reviewed including serology, detection of morulae in leukocytes, molecular methods, immunohistochemistry and isolation in cell cultures $[36,102]$.

Laboratory criteria for the diagnosis of both diseases have been defined by the Council of State and Territorial Epidemiologists [102]. They include demonstration of a fourfold or greater change in antibody titer to E. chaffeensis or A. phagocytophilum antigen by IFA in paired serum samples, or a positive PCR assay and confirmation of E. chaffeensis or A. phagocytophilum DNA, or identification of morulae in leukocytes and a positive IFA titer, or immunostaining E. chaffeensis or A. phagocytophilum antigen in a biopsy or autopsy sample, or culture of $E$. chaffeensis or A. phagocytophilum from a clinical specimen [102]. A confirmed case of human monocytic ehrlichiosis and human anaplasmosis requires a patient to have a clinically compatible illness that is laboratory confirmed. A probable case requires a patient to have a clinically compatible illness with either a single IFA titer at or above the cutoff dilution or the visualization of morulae in leukocytes. Recently, case definitions were also adopted in Europe by the study group for Coxiella, Anaplasma, Rickettsia and Bartonella of the European Society of Clinical Microbiology and Infectious Diseases [23]. Confirmed human granulocytic anaplasmosis definition requires (i) febrile illness with a history of a tick bite or tick exposure, and (ii) demonstration of $A$. phagocytophilum infection by seroconver- sion or $\geq 4$-fold change in serum antibody titers, or positive PCR result with subsequent sequencing of the amplicons demonstrating Anaplasma-specific DNA in the blood, or isolation of A. phagocytophilum in blood culture. A probable human granulocytic anaplasmosis definition corresponds to (i) a febrile illness with a history of a tick bite or tick exposure, and (ii) the presence of a stable titre of A. phagocytophilum antibodies in acute and convalescent sera if titre $>4$ times the cut off, or a positive PCR result without a sequence, or presence of intracytoplasmic morulae in a blood smear [23].

\subsection{Treatment}

Tetracyclines appear to be very effective in treating human ehrlichioses and anaplasmosis. E. chaffeensis has been found to also be susceptible to rifampin in vitro (without in vivo evidence) but resistant to aminoglycosides, macrolides and ketolides, cotrimoxazole, penicillin, cephalosporin, chloramphenicol and quinolones [102]. It was demonstrated in vitro, that fluoroquinolone resistance in E. chaffeensis is strongly correlated to the presence of a specific amino acid variation in a portion of the protein sequence of the A subunit of $(G y r A)$ [88]. When the antibiotic susceptibilities of eight strains of A. phagocytophilum collected in various geographic areas of the United States were recently tested in vitro, doxycycline and rifampin were the most active drugs [89]. However, levofloxacin was also active. Interestingly, no natural gyrase-mediated resistance to fluoroquinolones was demonstrated for A. phagocytophilum [88].

The optimal duration of doxycycline treatment in human ehrlichioses and anaplasmosis has yet to be determined. It is recommended that tetracycline treatment be continued for 7-10 days, or for at least 35 days after defervescence. Most patients become afebrile within 1-3 days following treatment $[96,102]$. 


\section{CONCLUSION AND PERSPECTIVES}

What are the factors influencing the emergence and recognition of tick- and flea borne rickettsial diseases in recent years? First, the major role of primary physicians should be emphasized, including their careful case history recording as well as their complete physical and laboratory examinations, since it was essential for the description of some emerging SFG rickettsioses, such as Flinders Island spotted fever, Japanese spotted fever and Astrakhan fever. Second, the recent availability of molecular biology techniques have been shown to greatly facilitate the description of emerging human rickettsioses and the investigation of their epidemiology all over the world. Third, improved culture systems have also allowed for incrimination of a new rickettsial species in human diseases. Finally, people are more involved in outdoor activities and there is an increased in the development of tourism in rural and/or remote areas resulting in increased contact with ticks and tickborne pathogens, as for the African tick-bite fever.

For human monocytic ehrlichioses, Paddock and Childs [102] recently presented several factors influencing the emergence of human monocytic ehrlichiosis (HME), particularly changes in the host-vector ecology. These include an increase in A. americanum density and geographic distribution, an increase in vertebrate-host populations (wild turkeys, white-tailed deer) for this tick, an increase in the reservoir host population for E. chaffeensis (i.e. white-tailed deer), an increased human contact with natural foci of infection through recreational and occupational activities, an increased frequency or severity of disease in aging or immunocompromised people, an increasing size and longevity of the population older than 60 years of age and immunocompromised populations in regions of enzootic infection, available diagnostic procedures and improved surveillance and reporting [102]. To date, HME has been definitely documented only in the USA. However, there has been an increasing number of publications suspecting its occurrence elsewhere in the world in recent years. Patients with antibodies reactive to $E$. chaffeensis or antigenically related to ehrlichiae have been reported in Europe, Asia, South America, Central America and even Africa [102]. As discussed elsewhere, these results have to be considered with caution since serosurvey results can be due to different bacteria but cross-reacting with $E$. chaffeensis, leading to misinterpretation [105]. DNA fragments closely related to those of $E$. chaffeensis have been detected by PCR in ticks from Russia [2], China [26, 152], Japan [137], and Vietnam [108]. This fact neither conclusively incriminates the corresponding ticks as efficient vectors nor is it evidence of the prevalence of the agent of HME outside the USA. Also, three different sequences of A. phagocytophilum have been recently detected by molecular tools in Ixodes persulcatus ticks from northeastern China and are identical to the published sequences of A. phagocytophilum responsible for human disease [27, 152].

Finally, numerous Rickettsia spp., Ehrlichia spp. or Anaplasma spp. have been identified in ticks throughout the world [22, $108,117,152]$. Although their pathogenicity for people has yet to be demonstrated, they are good candidates to be involved in human diseases since many of them have been detected in ticks that readily bite people. Therefore, more worldside studies could lead to the description of emerging human ehrlichioses and anaplasmoses in the future.

\section{REFERENCES}

[1] Adams J.R., Schmidtmann E.T., Azad A.F., Infection of colonized cat fleas, Ctenocephalides felis (Bouche), with a rickettsia-like microorganism, Am. J. Trop. Med. Hyg. 43 (1990) 400-409.

[2] Alekseev A.N., Dubinina H.V., Semenov A.V., Bolshakov C.V., Evidence of ehrlichiosis agents found in ticks (Acari: Ixodidae) 
collected from migratory birds, J. Med. Entomol. 38 (2001) 471-474.

[3] Anderson B.E., Greene C.E., Jones D.C., Dawson J.E., Ehrlichia ewingii sp. nov., the etiologic agent of canine granulocytic ehrlichiosis, Int. J. Syst. Bacteriol. 42 (1992) 299 302.

[4] Anderson B.E., Sims K.G., Olson J.G., Childs J.E., Piesman J.F., Happ C.M., Maupin G.O., Johnson B.J.B., Amblyomma americanum - a potential vector of human ehrlichiosis, Am. J. Trop. Med. Hyg. 49 (1993) 239-244.

[5] Anziani O.S., Ewing S.A., Barker R.W., Experimental transmission of a granulocytic form of the tribe Ehrlichieae by Dermacentor variabilis and Amblyomma americanum to dogs, Am. J. Vet. Res. 51 (1990) 929-931.

[6] Araki M., Takatsuka K., Kawamura J., Kanno Y., Japanese spotted fever involving the central nervous system: two case reports and a literature review, J. Clin. Microbiol. 40 (2002) 3874-3876.

[7] Arnez M., Petrovec M., Lotric-Furlan S., Zupanc T.A., Strle F., First European pediatric case of Human granulocytic ehrlichiosis, $\mathrm{J}$. Clin. Microbiol. 39 (2001) 4591-4592.

[8] Azad A.F., Radulovic S., Higgins J.A., Noden B.H., Troyer J.M., Flea-borne rickettsioses: ecologic considerations, Emerg. Infect. Dis. 3 (1997) 319-327.

[9] Baird R.W., Stenos J., Stewart R., Hudson B., Lloyd M., Aiuto S., Dwyer B., Genetic variation in Australian spotted fever group rickettsiae, J. Clin. Microbiol. 34 (1996) 1526-1530.

[10] Bakken J.S., Dumler J.S., Human granulocytic ehrlichiosis, Clin. Infect. Dis. 31 (2000) 554-560.

[11] Beati L., Meskini M., Thiers B., Raoult D., Rickettsia aeschlimannii sp. nov., a new spotted fever group rickettsia associated with Hyalomma marginatum ticks, Int. J. Syst. Bacteriol. 47 (1997) 548-554.

[12] Bermann F., Davoust B., Fournier P.E., BrisouLapointe A.V., Brouqui P., Ehrlichia equi (Anaplasma phagocytophila) infection in an adult horse in France, Vet. Rec. 150 (2002) 787-788.

[13] Billings A.N., Yu X.J., Teel F.D., Walker D.H., Detection of a spotted fever group rickettsia in Amblyomma cajennense (Acari: Ixodidae) in south Texas, J. Med. Entomol. 35 (1998) 474-478.

[14] Bjoersdorff A., Kristiansen B.E., Soderstrom C., Eliasson I., Varying clinical picture and course of human granulocytic ehrlichiosis. Twelve Scandinavian cases of the new tick- borne zoonosis are presented, Lakartidningen 96 (1999) 4200-4204 (in Swedish).

[15] Bjoersdorff A., Bergstrom S., Massung R.F., Maemig P.D., Olsen B., Ehrlichia-infected ticks on migrating birds, Emerg. Infect. Dis. 7 (2001) 877-879.

[16] Bjoersdorff A., Wittesjo B., Berglun J., Massung R.F., Eliasson I., Human granulocytic ehrlichiosis as a common cause of tick-associated fever in Southeast Sweden: report from a prospective clinical study, Scand. J. Infect. Dis. 34 (2002) 187-191.

[17] Bjoersdorff A., Bagert B., Massung R.F., Gusa A., Eliasson I., Isolation and characterization of two European strains of Ehrlichia phagocytophila of equine origin, Clin. Diagn. Lab. Immunol. 9 (2002) 341-343.

[18] Blanco J.R., Oteo J.A., Human granulocytic ehrlichiosis in Europe, Clin. Microbiol. Infect. 8 (2002) 763-772.

[19] Bouyer D.H., Stenos J., Crocquet-Valdes P., Moron C.G., Popov V.L., Zavala-Velazquez J.E., Foil L.D., Stothard D.R., Azad A.F., Walker D.H., Rickettsia felis: molecular characterization of a new member of the spotted fever group, Int. J. Syst. Evol. Microbiol. 51 (2001) 339-347.

[20] Bown K.J., Begon M., Bennett M., Woldehiwet Z., Ogden N.H., Seasonal dynamics of Anaplasma phagocytophila in a rodent-tick (Ixodes trianguliceps) system, United Kingdom, Emerg. Infect. Dis. 9 (2003) 63-70.

[21] Brouqui P., Ehrlichiosis in Europe, in: Raoult D., Brouqui P. (Eds.), Rickettsiae and rickettsial diseases at the turn of the third millenium, Elsevier, Paris, 1999, pp. 220-232.

[22] Brouqui P., Sanogo Y.O., Caruso G., Merola F., Raoult D., "Candidatus Ehrlichia walkerii": a new Ehrlichia detected in Ixodes ricinus tick collected from asymptomatic humans in Northern Italy, Ann. NY Acad. Sci. 990 (2003) 134-140.

[23] Brouqui P., Bacellar F., Baranton G., Birtles R.J., Bjoërsdorff A., Blanco J.R., Caruso G., Cinco M., Fournier P.E., FrancavillaE., Jensenius M., Kazar J., Laferl H., Lakos A., Lotric Furlan S., Maurin M., Oteo J.A., Parola P., Perez-Eid C., Peter O., Postic D., Raoult D., Tellez A., Tselentis Y., Wilske B., Guidelines for the diagnosis of tick-borne bacterial diseases in Europe, Clin. Microbiol. Infect. 10 (2005) 1108-1132.

[24] Buller R.S., Arens M., Hmiel S.P., Paddock C.D., Sumner J.W., Rikihisa Y., Unver A., Gaudreault-Keener R., Manian F.A., Liddell A.M., Schmulewitz N., Storch G.A., Ehrlichia ewingii, a newly recognized agent of 
human ehrlichiosis, N. Engl. J. Med. 341 (1999) 148-155.

[25] Burgdorfer W., Aeschlimann A., Peter O., Hayes S.F., Philip R.N., Ixodes ricinus vector of a hitherto undescribed spotted fever group agent in Switzerland, Acta Trop. 36 (1979) 357-367.

[26] Cao W.C., Gao Y.M., Zhang P.H., Zhang X.T., Dai Q.H., Dumler J.S., Fang L.Q., Yang H., Identification of Ehrlichia chaffeensis by nested PCR in ticks from southern China, J. Clin. Microbiol. 38 (2000) 2778-2780.

[27] Cao W.C., Zhao Q.M., Zhang P.H., Yang H., Wu X.M., Wen B.H., Zhang X.T., Habbema J.D.F., Prevalence of Anaplasma phagocytophila and Borrelia burgdorferi in Ixodes persulcatus ticks from northeastern China, Am. J. Trop. Med. Hyg. 68 (2003) 547-550.

[28] Cascio A., Colomba C., Antinori S., Paterson D.L., Titone L., Clarithromycin versus azithromycin in the treatment of Mediterranean spotted fever in children: a randomized controlled trial, Clin. Infect. Dis. 34 (2002) 154 158.

[29] Cazorla C., Enea M., Lucht F., Raoult D., First isolation of Rickettsia slovaca from a patient, France, Emerg. Infect. Dis. 9 (2003) 135.

[30] Chen S.M., Dumler J.S., Bakken J.S., Walker D.H., Identification of a granulocytotropic Ehrlichia species as the etiologic agent of human disease, J. Clin. Microbiol. 32 (1994) 589-595.

[31] Cohn L.A., Ehrlichiosis and related infections, Vet. Clin. North Am. Small Anim. Pract. 33 (2003) 863-884.

[32] Courtney J.W., Dryden R.L., Wyleto P., Schneider B.S., Massung R.F., Characterization of Anaplasma phagocytophila and Borrelia burgdorferi genotypes in Ixodes scapularis ticks from Pennsylvania, Ann. NY Acad. Sci. 990 (2003) 131-133.

[33] Daniels T.J., Battaly G.R., Liveris D., Falco R.C., Schwartz I., Avian reservoirs of the agent of human granulocytic ehrlichiosis? Emerg. Infect. Dis. 8 (2002) 1524-1525.

[34] Dawson J.E., Anderson B.E., Fishbein D.B., Sanchez J.L., Goldsmith C.S., Wilson K.H., Duntley C.W., Isolation and characterization of an Ehrlichia sp. from a patient diagnosed with Human ehrlichiosis, J. Clin. Microbiol. 29 (1991) 2741-2745.

[35] Drancourt M., Beati L., Tarasevich I., Raoult D., Astrakhan fever rickettsia is identical to Israel tick typhus rickettsia, a genotype of the Rickettsia conorii complex, J. Infect. Dis. 165 (1992) 1167-1168.

[36] Dumler J.S., Molecular methods for ehrlichiosis and Lyme disease, Clin. Lab. Med. 23 (2003) 867-884.
[37] Dumler J.S., Barbet A.F., Bekker C.P., Dasch G.A., Palmer G.H., Ray S.C., Rikihisa Y., Rurangirwa F.R., Reorganization of genera in the families Rickettsiaceae and Anaplasmataceae in the order Rickettsiales: unification of some species of Ehrlichia with Anaplasma, Cowdria with Ehrlichia and Ehrlichia with Neorickettsia, descriptions of six new species combinations and designation of Ehrlichia equi and "HGE agent" as subjective synonyms of Ehrlichia phagocytophila, Int. J. Syst. Evol. Microbiol. 51 (2001) 2145-2165.

[38] Eremeeva M.E., Balayeva N.M., Ignatovich V.F., Raoult D., Proteinic and genomic identification of spotted fever group rickettsiae isolated in the former USSR, J. Clin. Microbiol. 31 (1993) 2625-2633.

[39] Eremeeva M.E., Beati L., Makarova V.A., Fetisova N.F., Tarasevich I.V., Balayeva N.M., Raoult D., Astrakhan fever rickettsiae: antigenic and genotypic analysis of isolates obtained from human and Rhipicephalus pumilio ticks, Am. J. Trop. Med. Hyg. 51 (1994) 697-706.

[40] Ewing S.A., Roberson W.R., Buckner R.G., Hayat C.S., A new strain of Ehrlichia canis, J. Am. Vet. Med. Assoc. 159 (1971) 17711774.

[41] Ewing S.A., Dawson J.E., Kocan A.A., Barker R.W., Warner C.K., Panciera R.J., Fox J.C., Kocan K.M., Blouin E.F., Experimental transmission of Ehrlichia chaffeensis (Rickettsiales, Ehrlichieae) among white-tailed deer by Amblyomma americanum (Acari, Ixodidae), J. Med. Entomol. 32 (1995) 368-374.

[42] Fan M.Y., Zhang J.Z., Chen M., Yu X.J., Spotted fever group rickettsioses in China, in: Raoult D., Brouqui P. (Eds.), Rickettsiae and rickettsial diseases at the turn of the third millenium, Elsevier, Paris, 1999, pp. 247-257.

[43] Fernández-Soto P., Encinas-Grandes A., PérezSánchez R., Rickettsia aeschlimannii in Spain: molecular evidence in Hyalomma marginatum and five other tick species that feed on humans, Emerg. Infect. Dis. 9 (2003) 889890.

[44] Fournier P.E., Tissot-Dupont H., Gallais H., Raoult D., Rickettsia mongolotimonae: a rare pathogen in France, Emerg. Infect. Dis. 6 (2000) 290-292.

[45] Fournier P.E., Grunnenberger F., Jaulhac B., Gastinger G., Raoult D., Evidence of Rickettsia helvetica infection in humans, eastern France, Emerg. Infect. Dis. 6 (2000) 389-392.

[46] Fournier P.E., Fujita H., Takada N., Raoult D., Genetic identification of rickettsiae isolated from ticks in Japan, J. Clin. Microbiol. 40 (2002) 2176-2181. 
[47] Fournier P.E., Xeridat B., Raoult D., Isolation of a rickettsia related to Astrakhan fever rickettsia from a patient in Chad, Ann. NY Acad. Sci. 990 (2003) 152-157.

[48] Fournier P.E., Durand J.P., Rolain J.M., Camicas J.L., Tolou H., Raoult D., Detection of Astrakhan fever rickettsia from ticks in Kosovo, Ann. NY Acad. Sci. 990 (2003) 158-161.

[49] Fournier P.E., Dumler J.S., Greub G., Zhang J., Wu Y., Raoult D., Gene sequence-based criteria for identification of new rickettsia isolates and description of Rickettsia heilongjiangensis sp. nov., J. Clin. Microbiol. 41 (2003) 5456-5465.

[50] Fournier P.E., Raoult D., Suicide PCR on skin biopsies for the diagnosis of rickettsioses, J. Clin. Microbiol. 42 (2004) 3428-3434.

[51] Garcia-Perez A.L., Barandika J., Oporto B., Povedano I., Juste R.A., Anaplasma phagocytophila as an abortifacient agent in sheep farms from northern Spain, Ann. NY Acad. Sci. 990 (2003) 429-432.

[52] Gardner S.L., Holman R.C., Krebs J.W., Berkelman R., Childs J.E., National surveillance for the human ehrlichioses in the United States, 1997-2001, and proposed methods for evaluation of data quality, Ann. NY Acad. Sci. 990 (2003) 80-89.

[53] Goddard J., Experimental infection of lone star ticks, Amblyomma americanum (L.), with Rickettsia parkeri and exposure of guinea pigs to the agent, J. Med. Entomol. 40 (2003) 686689.

[54] Goethert H.K., Telford S.R., Enzootic transmission of the agent of human granulocytic ehrlichiosis among cottontail rabbits, Am. J. Trop. Med. Hyg. 68 (2003) 633-637.

[55] Goodman J.L., Nelson C., Vitale B., Madigan J.E., Dumler J.S., Kurtti T.J., Munderloh U.G., Direct cultivation of the causative agent of human granulocytic ehrlichiosis, N. Engl. J. Med. 334 (1996) 209-215. Erratum: N. Engl. J. Med. 335 (1996) 361.

[56] Goodman R.A., Hawkins E.C., Olby N.J., Grindem C.B., Hegarty B., Breitschwerdt E.B., Molecular identification of Ehrlichia ewingii infection in dogs: 15 cases (19972001), J. Am. Vet. Med. Assoc. 222 (2003) 1102-1107.

[57] Graves S., Stenos J., Rickettsia honei-A spotted fever group rickettsia on three continents, Ann. NY Acad. Sci. 990 (2003) 62-66.

[58] Hechemy K.E., Avsic-Zupanc T., Childs J.E., Raoultd D.A., Rickettsiology: Present and future directions - Preface, Ann. NY Acad. Sci. 990 (2003) XVII-XVXX.
[59] Higgins J.A., Radulovic S., Schriefer M.E., Azad A.F., Rickettsia felis: a new species of pathogenic rickettsia isolated from cat fleas, $\mathrm{J}$. Clin. Microbiol. 34 (1996) 671-674.

[60] Holman R.C., Paddock C.D., Curns A.T., Krebs J.W., McQuiston J.H., Childs J.E., Analysis of risk factors for fatal rocky mountain spotted fever: Evidence for superiority of tetracyclines for therapy, J. Infect. Dis. 184 (2001) 1437-1444.

[61] Inokuma H., Takahata H., Fournier P.E., Brouqui P., Raoult D., Okuda M., Onishi T., Nishioka K., Tsukahara M., Tick paralysis by Ixodes holocyclus in a Japanese traveler returning from Australia associated with Rickettsia helvetica infection, J. Travel Med. 10 (2003) 61-63.

[62] Jensenius M., Fournier P.E., Kelly P., Myrvang B., Raoult D., African tick bite fever, Lancet Infect. Dis. 3 (2003) 557-564.

[63] Jensenius M., Fournier P.E., Vene S., Hoel T., Hasle G., Henriksen A.Z., Hellum K.B., Raoult D., Myrvang B., African tick bite fever in travelers to rural sub-Equatorial Africa, Clin. Infect. Dis. 36 (2003) 1411-1417.

[64] Karlsson U., Bjoersdorff A., Christensson B., Human granulocytic ehrlichiosis - a clinical case in Scandinavia, Scand. J. Infect. Dis. 33 (2001) 73-74.

[65] Katayama T., Yoshida Y., Kaiho I., Spotted fever group rickettsiosis and vectors in Kanagawa prefecture, Kansenshogaku Zasshi 70 (1996) 561-568 (in Japanese).

[66] Kelly P.J., Mason P., Transmission of a spotted fever group rickettsia by Amblyomma hebraeum (Acari: Ixodidae), J. Med. Entomol. 28 (1991) 596-600.

[67] Kelly P.J., Mason P.R., Manning T., Slater S., Role of cattle in the epidemiology of tick-bite fever in Zimbabwe, J. Clin. Microbiol. 29 (1991) 256-259.

[68] Kelly P.J., Mason P.R., Rhode C., Dziva F., Matthewman L., Transient infections of goats with a novel spotted fever group rickettsia from Zimbabwe, Res. Vet. Sci. 51 (1991) 268-271.

[69] Kelly P.J., Meads N., Theobald A., Fournier P.E., Raoult D., Rickettsia felis, Bartonella henselae and Bartonella clarridgeiae, New Zealand, Emerg. Infect. Dis. 10 (2004)967-968.

[70] Kenny M.J., Birtles R.J., Day M.J., Shaw S.E., Rickettsia felis in the United Kingdom, Emerg. Infect. Dis. 9 (2003) 1023-1024.

[71] Kodama K., Senba T., Yamauchi H., Chikahira Y., Katayama T., Furuya Y., Fujita H., Yamamoto S., Fulminant japanese spotted fever definitively diagnosed by the polymerase 
chain reaction method, J. Infect. Chemother. 8 (2002) 266-268.

[72] Kodama K., Senba T., Yamauchi H., Nomura T., Chikahira Y., Clinical study of Japanese spotted fever and its aggravating factors, J. Infect. Chemother. 9 (2003) 83-87.

[73] Kollars T.M. Jr., Tippayachai B., Bodhidatta D., Short report: Thai tick typhus, Rickettsia honei, and a unique rickettsia detected in Ixodes granulatus (Ixodidae: Acari) from Thailand, Am. J. Trop. Med. Hyg. 65 (2001) 535537.

[74] Komitova R., Lakos A., Aleksandrov A., Christova I., Murdjeva M., A case of ticktransmitted lymphadenopathy in Bulgaria associated with Rickettsia slovaca, Scand. J. Infect. Dis. 35 (2003) 213.

[75] La Scola B., Raoult D., Laboratory diagnosis of rickettsioses: current approaches to diagnosis of old and new rickettsial diseases, J. Clin. Microbiol. 35 (1997) 2715-2727.

[76] La Scola B., Meconi S., Fenollar F., Rolain J.M., Roux V., Raoult D., Emended description of Rickettsia felis (Bouyer et al. 2001), a temperature-dependent cultured bacterium, Int. J. Syst. Evol. Microbiol. 52 (2002) 20352041.

[77] Lane R.S., Steinlein D.B., Mun J., Human behaviors elevating exposure to Ixodes pacificus (Acari: Ixodidae) nymphs and their associated bacterial zonotic agents in hardwood forest, J. Med. Entomol. 41 (2004) 239-248.

[78] Liz J.S., Anderes L., Sumner J.W., Massung R.F., Gern L., Rutti B., Brossard M., PCR detection of granulocytic Ehrlichiae in Ixodes ricinus ticks and wild small mammals in western Switzerland, J. Clin. Microbiol. 38 (2000) 1002-1007.

[79] Long S.W., Zhang X., Zhang J., Ruble R.P., Teel P., Yu X.J., Evaluation of transovarial transmission and transmissibility of Ehrlichia chaffeensis (Rickettsiales: Anaplasmataceae) in Amblyomma americanum (Acari: Ixodidae), J. Med. Entomol. 40 (2003) 1000-1004.

[80] Lotric-Furlan S., Petrovec M., Zupanc T.A., Nicholson W.L., Sumner J.W., Childs J.E., Strle F., Human granulocytic ehrlichiosis in Europe: clinical and laboratory findings for four patients from Slovenia, Clin. Infect. Dis. 27 (1998) 424-428.

[81] Maeda K., Markowitz N., Hawley R.C., Ristic M., Cox D., McDade J.E., Human infection with Ehrlichia canis, a leukocytic Rickettsia, N. Engl. J. Med. 316 (1987) 853-856.

[82] Mahara F., Three Weil-Felix reaction OX2 positive cases with skin eruptions and high fever, J. Anan. Med. Assoc. 68 (1984) 4-7.
[83] Mahara F., Japanese spotted fever: Report of 31 cases and review of the literature, Emerg. Infect. Dis. 3 (1997) 105-111.

[84] Mahara F., Rickettsioses in Japan, in: Raoult D., Brouqui P. (Eds.), Rickettsiae and rickettsial diseases at the turn of the third millenium, Elsevier, Paris, 1999, pp. 233-239.

[85] Marquez F.J., Muniain M.A., Perez J.M., Pachon J., Presence of Rickettsia felis in the cat flea from southwestern Europe, Emerg. Infect. Dis. 8 (2002) 89-91.

[86] Massung R.F., Mauel M.J., Owens J.H., Allan N., Courtney J.W., Stafford K.C. 3rd, Mather T.N., Genetic variants of Ehrlichia phagocytophila, Rhode Island and Connecticut, Emerg. Infect. Dis. 8 (2002) 467-472.

[87] Masters E.J., Olson G.S., Weiner S.J., Paddock C.D., Rocky mountain spotted fever, A clinician's dilemma, Arch. Intern. Med. 163 (2003) 769-774.

[88] Maurin M., Abergel C., Raoult D., DNA gyrase-mediated natural resistance to fluoroquinolones in Ehrlichia spp., Antimicrob. Agents Chemother. 45 (2001) 2098-2105.

[89] Maurin M., Bakken J.S., Dumler J.S., Antibiotic susceptibilities of Anaplasma (Ehrlichia) phagocytophilum strains from various geographic areas in the United States, Antimicrob. Agents. Chemother. 47 (2003) 413-415.

[90] Misic-Majerus L.J., Madjaric V., Janes-Poje V., First description of the human granulocytic ehrlichiosis in Croatia, Clin. Microbiol. Infect. 6 (2000) 194-195.

[91] Munderloh U.G., Jauron S.D., Fingerle V., Leitritz L., Hayes S.F., Hautman J.M., Nelson C.M., Huberty B.W., Kurtti T.J., Ahlstrand G.G., Greig B., Mellencamp M.A., Goodman J.L., Invasion and intracellular development of the human granulocytic ehrlichiosis agent in tick cell culture, J. Clin. Microbiol. 37 (1999) 2518-2524.

[92] Nadelman R.B., Horowitz H.W., Hsieh T.C., Wu J.M., AgueroRosenfeld M.E., Schwartz I., Nowakowski J., Varde S., Wormser G.P., Simultaneous human granulocytic ehrlichiosis and Lyme borreliosis, N. Engl. J. Med. 337 (1997) 27-30.

[93] Neer T.M., Breitschwerdt E.B., Greene R.T., Lappin M.R., Consensus statement on ehrlichial disease of small animals from the Infectious Study Group of the ACVIM, J. Vet. Intern. Med. 16 (2002) 309-315.

[94] Niebylski M.L., Peacock M.G., Schwan T.G., Lethal effect of Rickettsia rickettsii on its tick vector (Dermacentor andersoni), Appl. Environ. Microbiol. 65 (1999) 773-778.

[95] Ogden N.H., Casey A.N., French N.P., Woldehiwet Z., A review of studies on the transmission of Anaplasma phagocytophilum 
from sheep: implications for the force of infection in endemic cycles, Exp. Appl. Acarol. 28 (2002) 195-202.

[96] Olano J.P., Walker D.H., Human ehrlichioses, Med. Clin. North Am. 86 (2002) 375392.

[97] Olano J.P., Masters E., Hogrefe W., Walker D.H., Human monocytotropic ehrlichiosis, Missouri, Emerg. Infect. Dis. 9 (2003) 1579_ 1586.

[98] Oliveira R.P., Galvao M.A., Mafra C.L., Chamone C.B., Calic S.B., Silva S.U., Walker D.H., Rickettsia felis in Ctenocephalides spp. fleas, Brazil, Emerg. Infect. Dis. 8 (2002) 317-319.

[99] Oporto B., Gil H., Barral M., Hurtado A., Juste R.A., Garcia-Perez A.L., A survey on Anaplasma phagocytophila in wild small mammals and roe deer (Capreolus capreolus) in Northern Spain, Ann. NY Acad. Sci. 990 (2003) 98-102.

[100] Oteo J.A., Blanco J.R., Martinez de Artola V., Ibarra V., First report of human granulocytic ehrlichiosis from southern Europe (Spain), Emerg. Infect. Dis. 6 (2000) 430 432. Erratum in: 6 (2000) 562 and 663.

[101] Oteo J.A., Ibarra V., Blanco J.R., Vallejo M., De Artola V.M., Epidemiological and clinical differences among Rickettsia slovaca rickettsiosis and other tick-borne diseases in Spain, Ann. NY Acad. Sci. 990 (2003) 355356.

[102] Paddock C.D., Childs J.E., Ehrlichia chaffeensis: a prototypical emerging pathogen, Clin. Microbiol. Rev. 16 (2003) 37-64.

[103] Paddock C.D., Folk S.M., Shore G.M., Machado L.J., Huycke M.M., Slater L.N., Liddell A.M., Buller R.S., Storch G.A., Monson T.P., Rimland D., Sumner J.W., Singleton J., Bloch K.C., Tang Y.W., Standaert S.M., Childs J.E., Infections with Ehrlichia chaffeensis and Ehrlichia ewingii in persons coinfected with human immunodeficiency virus, Clin. Infect. Dis. 33 (2001) 15861594.

[104] Paddock C.D., Sumner J.W., Comer J.A., Zaki S.R., Goldsmith C.C., Goddard J., McLellan S.L.F., Tamminga C.L., Ohl C.A., Rickettsia parkeri: a newly recognized cause of spotted fever rickettsiosis in the United States, Clin. Infect. Dis. 38 (2004) 805-811.

[105] Parola P., Raoult D., Ticks and tickborne bacterial diseases in humans: an emerging infectious threat, Clin. Infect. Dis. 32 (2001) 897-928. Erratum: Clin. Infect. Dis. 33 (2001) 749.

[106] Parola P., Inokuma H., Camicas J.L., Brouqui P., Raoult D., Detection and identification of spotted fever group Rickettsiae and Ehrlichiae in African ticks, Emerg. Infect. Dis. 7 (2001) 1014-1017.

[107] Parola P., Miller R.S., McDaniel P., Telford S.R. III, Rolain J.M., Wongsrichanalai C., Raoult D., Emerging rickettsioses of the Thai-Myanmar border, Emerg. Infect. Dis. 9 (2003) 592-595.

[108] Parola P., Cornet J.P., Sanogo Y.O., Miller R.S., Thien H.V., Gonzalez J.P., Raoult D., Telford S.R. III, Wongsrichanalai C., Detection of Ehrlichia spp., Anaplasma spp., Rickettsia spp., and other eubacteria in ticks from the Thai-Myanmar border and Vietnam, J. Clin. Microbiol. 41 (2003) 1600-1608.

[109] Parola P., Sanogo Y.O., Lerdthusnee K., Zeaiter Z., Chauvancy G., Gonzalez J.P., Miller R.S., Telford S.R. III, Wongsrichanalai C., Raoult D., Identification of Rickettsia spp. and Bartonella spp. in fleas from the Thai-Myanmar border, Ann. NY Acad. Sci. 990 (2003) 173-181.

[110] Petrovec M., Lotric F.S., Zupanc T.A., Strle F., Brouqui P., Roux V., Dumler J.S., Human disease in Europe caused by a granulocytic Ehrlichia species, J. Clin. Microbiol. 35 (1997) 1556-1559.

[111] Petrovec M., Sixl W., Schweiger R., Mikulasek S., Elke L., Wust G., Marth E., Strasek K., Stunzner D., Avsic-Zupanc T., Infections of wild animals with Anaplasma phagocytophila in Austria and the Czech Republic, Ann. NY Acad. Sci. 990 (2003) 103-106.

[112] Pretorius A.M., Birtles R.J., Rickettsia aeschlimannii: A new pathogenic spotted fever group rickettsia, South Africa, Emerg. Infect. Dis. 8 (2002) 874.

[113] Pretorius A.M., Birtles R., Rickettsia mongolotimonae infection in South Africa, Emerg. Infect. Dis. 10 (2004) 125-126.

[114] Purvis J.J., Edwards M.S., Doxycycline use for rickettsial disease in pediatric patients, Pediatr. Infect. Dis. J. 19 (2000) 871-874.

[115] Radulovic S., Higgins J.A., Jaworski D.C., Azad A.F., In vitro and in vivo antibiotic susceptibilities of ELB rickettsiae, Antimicrob. Agents Chemother. 39 (1995) 2564-2566.

[116] Raoult D., A new tick-borne rickettsiosis in the USA, Clin. Infect. Dis. 38 (2004) 812 813.

[117] Raoult D., Roux V., Rickettsioses as paradigms of new or emerging infectious diseases, Clin. Microbiol. Rev. 10 (1997) 694719 .

[118] Raoult D., Brouqui P., Roux V., A new spotted-fever-group rickettsiosis, Lancet 348 (1996) 412. 
[119] Raoult D., Fournier P.E., Fenollar F., Jensenius M., Prioe T., de Pina J.J., Caruso G., Jones N., Laferl H., Rosenblatt J.E., Marrie T.J., Rickettsia africae, a tick-borne pathogen in travelers to sub-Saharan Africa, N. Engl. J. Med. 344 (2001) 1504-1510.

[120] Raoult D., La Scola B., Enea M., Fournier P.E., Roux V., Fenollar F., Galvao M.A., de Lamballerie X., A flea-associated Rickettsia pathogenic for humans, Emerg. Infect. Dis. 7 (2001) 73-81.

[121] Raoult D., Fournier P.E., Abboud P., Caron F., First Documented Human Rickettsia aeschlimannii Infection, Emerg. Infect. Dis. 8 (2002) 748-749.

[122] Raoult D., Lakos A., Fenollar F., Beytout J., Brouqui P., Fournier P.E., Spotless rickettsiosis caused by Rickettsia slovaca and associated with Dermacentor ticks, Clin. Infect. Dis. 34 (2002) 1331-1336.

[123] Rehacek J., Rickettsia slovaca, the organism and its ecology, Acta Scientiarum Naturalium Academiae Scientiarum Bohemoslovacae (Brno) 18 (1984) 1-50.

[124] Remy V., Hansmann Y., De Martino S., Christmann D., Brouqui P., Human anaplasmosis presenting as atypical pneumonitis in France, Clin. Infect. Dis. 37 (2003) 846-848.

[125] Richter J., Fournier P.E., Petridou J., Haussinger D., Raoult D., Rickettsia felis infection acquired in Europe and documented by polymerase chain reaction, Emerg. Infect. Dis. 8 (2002) 207-208.

[126] Ricketts H.T., The transmission of Rocky Mountain spotted fever by the bite of the wood tick (Dermacentor occidentalis), JAMA 47 (1906) 358.

[127] Rikihisa Y., The tribe Ehrlichieae and ehrlichial diseases, Clin. Microbiol. Rev. 4 (1991) 286-308.

[128] Rikihisa Y., Mechanisms to create a safe haven by members of the family Anaplasmataceae, Ann. NY Acad. Sci. 990 (2003) 548-555.

[129] Rolain J.M., Maurin M., Vestris G., Raoult D., In vitro susceptibilities of 27 rickettsiae to 13 antimicrobials, Antimicrob. Agents Chemother. 42 (1998) 1537-1541.

[130] Rolain J.M., Franc M., Davoust B., Raoult D., Molecular detection of pathogenic Bartonella and Rickettsia in cat fleas from France, Emerg. Infect. Dis. 9 (2003) 338-342.

[131] Ruscio M., Cinco M., Human granulocytic ehrlichiosis in Italy: first report on two confirmed cases, Ann. NY Acad. Sci. 990 (2003) $350-352$
[132] Sanogo Y.O., Parola P., Shpynov S., Camicas J.L., Brouqui P., Caruso G., Raoult D., Genetic diversity of bacterial agents detected in ticks removed from asymptomatic patients in northeastern Italy, Ann. NY Acad. Sci. 990 (2003) 182-190.

[133] Scarpulla M., Caristo M.E., Macri G., Lillini E., Equine ehrlichiosis in Italy, Ann. NY Acad. Sci. 990 (2003) 259-263.

[134] Schriefer M.E., Sacci J.B., Dumler J.S., Bullen M.G., Azad A.F., Identification of a novel rickettsial infection in a patient diagnosed with murine typhus, J. Clin. Microbiol. 32 (1994) 949-954.

[135] Segura F., Anton E., Clarithromycin for the treatment of Mediterranean spotted fever, Clin. Infect. Dis. 34 (2002) 560.

[136] Sexton D.J., Corey G.R., Carpenter C., Kong L.Q., Gandhi T., Breitschwerdt E., Hegarty B., Chen S.M., Feng H.M., Yu X.J., Olano J., Walker D.H., Dumler S.J., Dual infection with Ehrlichia chaffeensis and a spotted fever group rickettsia: a case report, Emerg. Infect. Dis. 4 (1998) 311-316.

[137] Shibata S., Kawahara M., Rikihisa Y., Fujita H., Watanabe Y., Suto C., Ito T., New Ehrlichia species closely related to Ehrlichia chaffeensis isolated from Ixodes ovatus ticks in Japan, J. Clin. Microbiol. 38 (2000) 13311338 .

[138] Sikora H., Beitrage zur Kenntnis der Rickettsien, Arch. Schiffs- u. Tropenhygien (Liepzig) xxii (1918) 442-446.

[139] Sixl W., Petrovec M., Marth E., Wust G., Stunzner D., Schweiger R., Avsic-Zupanc T., Investigation of Anaplasma phagocytophila infections in Ixodes ricinus and Dermacentor reticulatus ticks in Austria, Ann. NY Acad. Sci. 990 (2003) 94-97.

[140] Stenos J., Roux V., Walker D., Raoult D., Rickettsia honei sp. nov., the aetiological agent of Flinders Island spotted fever in Australia, Int. J. Syst. Bacteriol. 48 (1998) 13991404 .

[141] Stewart R.S., Flinders Island spotted fever: a newly recognised endemic focus of tick typhus in Bass Strait. Part 1, Clinical and epidemiologiocal features, Med. J. Austr. 154 (1991) 94-99.

[142] Stuen S., Nevland S., Moum T., Fatal cases offick-borne fever (TBF) in sheep caused by several 16S rRNA gene variants of Anaplasma phagocytophilum, Ann. NY Acad. Sci. 990 (2003) 433-434.

[143] Tarasevich I.V., Makarova V.A., Fetisova N.F., Stepanov A.V., Miskarova E.D., Balayeva N., Raoult D., Astrakhan fever, a spotted-fever rickettsiosis, Lancet 337 (1991) 172-173. 
[144] Tozon N., Petrovec M., Avsic-Zupanc T., Clinical and laboratory features of the first detected cases of A. phagocytophila infections in dogs from Slovenia, Ann. NY Acad. Sci. 990 (2003) 424-428.

[145] Tylewska-Wierzbanowska S., Chmielewski T., Kondrusik M., Hermanowska-Szpakowicz T., Sawicki W., Sulek K., First cases of acute human granulocytic ehrlichiosis in Poland, Eur. J. Clin. Microbiol. Infect. Dis. 20 (2001) 196-198.

[146] Uchida T., Uchiyama T., Kumamo K., Walker D.H., Rickettsia japonica sp. nov., the etiological agent of spotted fever group rickettsiosis in Japan, Int. J. Syst. Bacteriol. 42 (1992) 303-305.

[147] Van Dobbenburgh A., van Dam A.P., Fikrig E., Human granulocytic ehrlichiosis in western Europe, N. Engl. J. Med. 340 (1999) 1214-1216.

[148] Vestris G., Rolain J.M., Fournier P.E., Birg M.L., Enea M., Patrice J.Y., Raoult D., Seven years' experience of isolation of Rickettsia spp. from clinical specimens using the shell vial cell culture assay, Ann. NY Acad. Sci. 990 (2003) 371-374.

[149] Walder G., Falkensammer B., Aigner J., Tiwald G., Dierich M.P., Wurzner R., Lechleitner P., First documented case of human granulocytic ehrlichiosis in Austria, Wien. Klin. Wochenschr. 115(2003) 263-266.

[150] Walker D.H., Valbuena G.A., Olano J.P., Pathogenic mechanisms of diseases caused by Rickettsia, Ann. NY Acad. Sci. 990 (2003) 1-11.

[151] Watt G., Parola P., Scrub typhus and tropical rickettsioses, Curr. Opin. Infect. Dis. 16 (2003) 429-436.
[152] Wen B.H., Cao W.C., Pan H., Ehrlichiae and ehrlichial diseases in China, Ann. NY Acad. Sci. 990 (2003) 45-53.

[153] Whitworth T., Popov V., Han V., Bouyer D., Stenos J., Graves S., Ndip L., Walker D., Ultrastructural and genetic evidence of a reptilian tick, Aponomma hydrosauri, as a host of Rickettsia honei in Australia - Possible transovarial transmission, Ann. NY Acad. Sci. 990 (2003) 67-74.

[154] Wolbach S.B., Studies on rocky mountain spotted fever, J. Med. Res. 41 (1919) 1-70.

[155] Wolf L., McPherson T., Harrison B., Engber B., Anderson A., Whitt P., Prevalence of Ehrlichia ewingii in Amblyomma americanum in North Carolina, J. Clin Microbiol. 38 (2000) 2795.

[156] Yabsley M.J., Varela A.S., Tate C.M., Dugan V.G., Stallknecht D.E., Little S.E., Davidson W.R., Ehrlichia ewingii infection in white-tailed deer (Odocoileus virginianus), Emerg. Infect. Dis. 8 (2002) 668671 .

[157] Yu X., Jin Y., Fan M., Xu G., Liu Q., Raoult D., Genotypic and antigenic identification of two new strains of spotted fever group rickettsiae isolated from China, J. Clin. Microbiol. 31 (1993) 83-88.

[158] Zavala-Velazquez J.E., Ruiz-Sosa J.A., Sanchez-Elias R.A., Becerra-Carmona G., Walker D.H., Rickettsia felis rickettsiosis in Yucatan, Lancet 356 (2000) 1079-1080.

[159] Zeidner N.S., Burkot T.R., Massung R., Nicholson W.L., Dolan M.C., Rutherford J.S., Biggerstaff B.J., Maupin G.O., Transmission of the agent of human granulocytic ehrlichiosis by Ixodes spinipalpis ticks: evidence of an enzootic cycle of dual infection with Borrelia burgdorferi in Northern Colorado, J. Infect. Dis. 182 (2000) 616-619. 